\title{
Landscape Changes in Protected Areas in Poland
}

\author{
Anna Zbierska
}

Citation: Zbierska, A. Landscape Changes in Protected Areas in

Poland. Sustainability 2022, 14, 753.

https://doi.org/10.3390/su14020753

Academic Editors: Anna

Maria Colavitti, Chiara Garau and

Sergio Serra

Received: 7 December 2021

Accepted: 7 January 2022

Published: 11 January 2022

Publisher's Note: MDPI stays neutral with regard to jurisdictional claims in published maps and institutional affiliations.

Copyright: (C) 2022 by the author Licensee MDPI, Basel, Switzerland. This article is an open access article distributed under the terms and conditions of the Creative Commons Attribution (CC BY) license (https:// creativecommons.org/licenses/by/ $4.0 /)$.
Faculty of Environmental and Mechanical Engineering, Poznan University of Life Science, 60-637 Poznan, Poland; anna.zbierska@up.poznan.pl

\begin{abstract}
Land-Use Cover Changes (LUCCs) are one of the main problems for the preservation of landscapes and natural biodiversity. Protected Areas (PAs) do not escape this threat. Poland is among the European leaders in terms of the variety of landscapes and the share of an area designated as a protected area. However, as many as $78 \%$ of the habitats have poor or bad conservation status based on EEA reports. This article analyzes the LUCCs between 2000 and 2018 in various types of the Polish legal forms of nature protection areas and the European Natura 2000 network within the country. The research material was: the data of Corine Land Cover (CLC), the Central Register of Nature Protection Forms, and high-resolution layers, such as HRL and orthophotos. The results were compiled according to the CLC class and forms of protection. The matrix of transformations showed that the most frequently transformed CLC class was 312 (coniferous forest). It was transformed into class 324 (transitional woodland shrubs). The changes in PAs were usually smaller than in the surrounding buffer zones, which may indicate their effectiveness. The exception was the areas of the European Natura 2000 network. The scale of land-cover flows (LCFs) changed within particular forms of protected areas, though afforestation and deforestation predominating in all area types. National reserves and parks were the most stable in terms of land cover structures. However, human settlements increased around the protected areas, potentially increasing threats to their ecological integrity.
\end{abstract}

Keywords: landscape change; protected area; urban pressure; deforestation; land use; CORINE land cover; Poland

\section{Introduction}

Protected areas (PAs) are the cornerstone of global biodiversity conservation strategies $[1,2]$. They are a key for mitigating climate change, providing ecosystem services, and fostering human well-being [3,4]. There is considerable evidence that well-managed protected areas are effective in reducing biodiversity loss [5-11]. However, not all protected areas are fulfilling their conservation objectives [12-15]. As the human population increases, pressures on habitats are intensifying with unknown consequences for protected area effectiveness [16-20], and recent work has identified a range of drivers of biodiversity loss in protected areas [18-22].

The inception and growth of a protected area network are one of the major global responses to rapid habitat loss and fragmentation, to counter the threats of the propagation of invasive species, deforestation, climate change, and urban and agricultural pressure. In 1990, PAs covered $8.6 \%$ of the Earth's surface [23], and now occupy $16.44 \%$ of the Earth's land surface, and $7.73 \%$ of the marine area [23]. According to the World Database of Protected Areas (WDPA) [23], they have expanded from 84,577 individual sites in 2003 to 258,133 in 2021, covering 245 countries and territories. The highest coverage of protected areas is in the Polar region (over $41 \%$ terrestrial and $44 \%$ marine) (Table 1). Europe has the largest number of sites, but they cover only $13 \%$ of the land area and $8 \%$ of the marine area [23]. 
Table 1. Protected areas in the world.

\begin{tabular}{|c|c|c|c|c|c|}
\hline Region & $\begin{array}{c}\text { Total Protected } \\
\text { Areas }\end{array}$ & $\begin{array}{l}\text { With Management } \\
\text { Effectiveness } \\
\text { Evaluations }\end{array}$ & $\begin{array}{l}\text { Number of } \\
\text { Countries }\end{array}$ & $\begin{array}{c}\text { Terrestrial Protected } \\
\text { Area Coverage \% }\end{array}$ & $\begin{array}{l}\text { Marine Protected } \\
\text { Area Coverage \% }\end{array}$ \\
\hline Asia \& Pacific & 34,710 & 2821 & 56 & 15.37 & 18.56 \\
\hline Africa & 8559 & 1000 & 58 & 14.11 & 12.35 \\
\hline Europe & 158,452 & 15,719 & 62 & 13.14 & 8.44 \\
\hline Latin America \& & 9971 & 1282 & 52 & 24.21 & 23.04 \\
\hline Polar & 35 & 3 & 5 & 41.28 & 44.78 \\
\hline North America & 45,272 & 117 & 3 & 11.85 & 16.51 \\
\hline West Asia & 378 & 65 & 12 & 3.82 & 1.11 \\
\hline
\end{tabular}

UNEP-WCMC (2021). Protected Area Profile from the World Database of Protected Areas, May 2021. Available at: www.protectedplanet.net, accessed on 5 May 2021.

These values may be slightly different from the national data. According to the European Environment Agency (EEA) in 2020, protected areas covered 26\% of EU land, with $18 \%$ designated as Natura 2000 sites and $8 \%$ as other national designations [24]. The area and number of terrestrial protected areas in Europe has grown steadily over time, where the biggest increases were in the 1990s (Figure 1) [24,25]. In EEA-38 countries (plus the United Kingdom), this coverage is lower and amounts to 23\%. In Poland-one of the largest countries in the European Union (EU) selected as the study area for further detailed analyses-the number of PA objects according to WDPA is 3091, covering $39.54 \%$ of the land area [23]. National data indicate that there are 10,884 sites (surface forms of national legal nature protection) and 995 sites protected under the European Natura 2000 Network, covering a total of $43.88 \%$ of the country's land area [26,27].

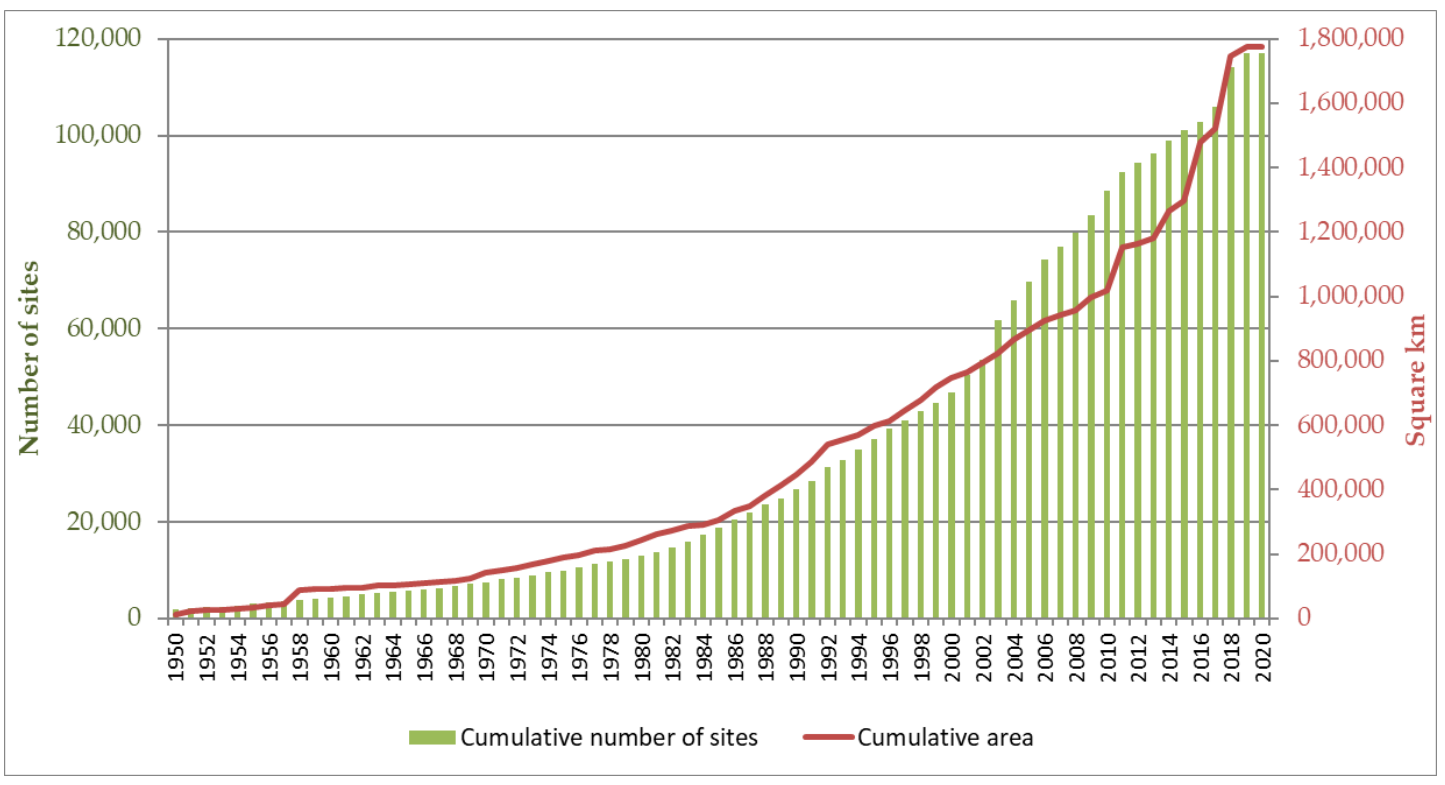

Figure 1. Increase in the number and size of nationally designated protected areas in Europe (EEA-38 + UK), 1950-2020 (Source: Nationally designated areas (CDDA) reported in 2020, provided by the European Environment Agency (EEA)).

To achieve the target of legally protecting a minimum of $30 \%$ of EU land, as set out in the EU biodiversity strategy for 2030, further expansion of terrestrial protected areas will be needed. However, the designation of protected areas is not in itself a guarantee of biodiversity conservation. Unfortunately, the increase in the number and area of protected areas does not directly transpose to the conservation status of habitats. At the EU level, only $23.87 \%$ of habitat assessments have good conservation status, with $72.39 \%$ having poor or bad conservation status [28]. Grasslands, dunes, and bog, mire, and fen habitats show strong deteriorating trends, while forests have the most improving trends. Intensive agriculture, urban sprawl, and pollution are the top reported pressures on habitats. Against 
this background, Poland (PL) looks even worse. As many as $78.26 \%$ of the habitats have poor or bad conservation status (Figure 2) [28]. Even though Poland is among the European leaders in terms of the share of an area designated as a terrestrial protected area (fourth place out of 32 EEA member countries [24]), it ranks only 16th in terms of the conservation status of habitats [28].

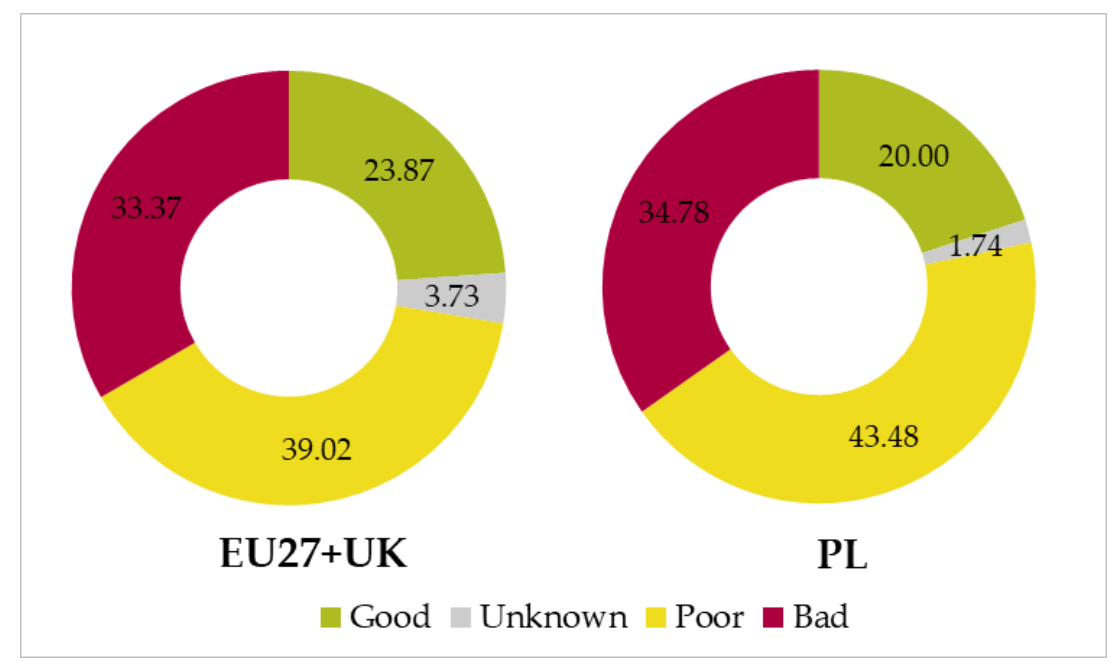

Figure 2. Conservation status of habitats at EEA Member State level (EU27+UK) and in Poland (PL), 2013-2018 (based on the conservation status of habitat type datasets from Article 17, Habitats Directive 92/43/EEC report provided by EEA).

Many protected areas may not be adequately safeguarding biodiversity from human activities on surrounding lands and global change. The magnitude of such change agents and the sensitivity of ecosystems to these agents vary among protected areas [29,30]. Thus, there is a need to assess vulnerability across networks of protected areas to determine those most at risk.

The main objective of this research was to analyze the changes in land use that occurred between 2000 and 2018, in various types of nature protection areas listed in the Polish Central Register of the Forms of Nature Protection and the European Natura 2000 network within the country. The processes that have occurred inside the different types of PAs forms were compared with those that have occurred outside of them (nPA), in their surroundings, in order to find substantial differences relating to environmental sustainability. The ultimate aim of the research was to provide information that will be of use to the managers of affected PAs and local administrators in their preventive environmental and territorial decisions.

\section{Materials and Methods}

\subsection{Study Area}

The study covers various types of nature protection areas in Poland distinguished in the Nature Conservation Act of 16 April 2004 [31]. Poland is characterized by great landscape diversity, from sea landscapes through to lakelands, forests, agricultural landscapes, and alpine mountain landscapes. Even on a European scale, Poland is distinguished by a significant share of semi-natural areas. Unfortunately, there are almost no completely natural areas without any trace of human influence. Striving to preserve its most natural habitats, Poland has, for many years, been developing various forms of the legal protection of natural areas, which may overlap with each other. These forms include national parks, landscape parks, nature reserves, protected landscape areas, ecological lands, nature and landscape complexes, and documentary sites. In total, protected areas cover almost $44 \%$ of the country's area, which places Poland among the leaders in the EU [24,26].

According to the Nature Conservation Act, there are 10 forms of nature conservation in Poland (Table 2): 8 forms of surface protection and 2 forms of individual protection 
(objects or species) [31]. The Polish definitions of these areas do not always coincide with International Union for Conservation of Nature (IUCN) categories of protected areas (Figure 3). For example, according to the criteria used by the IUCN, none of the 1499 Polish nature reserves has been classified as a Strict Nature Reserve (category I), and only 1 is classified as Ib (Wilderness area). The remaining majority was classified into the "Not Reported" group. Furthermore, only 16 of 23 Polish national parks have the status of an "international" national park (category II), while the rest are classified as category V, a protected landscape area, or not reported [23].

Table 2. List of nature conservation forms in Poland.

\begin{tabular}{|c|c|c|c|c|c|}
\hline \multirow{2}{*}{ No. } & \multirow{2}{*}{ Nature Conservation Form } & \multicolumn{2}{|c|}{ Number of Sites } & \multicolumn{2}{|c|}{ Area [Thousand Hectares] * } \\
\hline & & 2000 & 2020 & 2000 & 2020 \\
\hline 1. & Nature reserves & 1307 & 1499 & 148.7 & 169.6 \\
\hline 2. & National parks & 22 & 23 & 306.5 & 315.1 \\
\hline 3. & Landscape parks & 120 & 124 & 2446.9 & 2531.8 \\
\hline 4. & Natura 2000 areas & $x$ & $\begin{array}{l}145 \text { (SPAs) } \\
849 \text { (SACs) }\end{array}$ & $\mathrm{x}$ & $\begin{array}{l}4911.4 \text { (SPAs) } \\
3491.3 \text { (SACs) }\end{array}$ \\
\hline 5. & Protected landscape areas & 407 & 407 & 7137.7 & 6925.6 \\
\hline 6. & Landscape-nature complexes & 170 & 263 & 78.1 & 118.8 \\
\hline 7. & Ecological areas & 6113 & 7654 & 44.9 & 55.4 \\
\hline 8. & Documentation sites & 103 & 178 & 1.0 & 1.0 \\
\hline 9. & Monuments of nature & 33094 & 34890 & $\mathrm{x}$ & $x$ \\
\hline 10. & $\begin{array}{l}\text { Plants, animals, and fungi species } \\
\text { protection }\end{array}$ & \multicolumn{2}{|c|}{$\begin{array}{l}715 \text { plants species } \\
322 \text { fungi species } \\
801 \text { animals species }\end{array}$} & $\mathrm{x}$ & $\mathrm{x}$ \\
\hline
\end{tabular}

SPAs—special protection sites (Birds Directive) (PLB). SACs-special sites of conservation (Habitats Directive) (PLH). * Terrestrial area only (do not include information about marine areas), due to the overlapping of the boundaries of various forms of nature conservation, the areas do not correspond to the sum of the total area designated as a terrestrial protected area. $x-$ not applicable. Data in points 1-9-Source: Central Register of the Forms of Nature Protection, crfop.gdos.gov.pl (3 March 2021, regularly updated data); data in points 10—Source: General Directorate for Environmental Protection (January 2015)—data refer to native species.

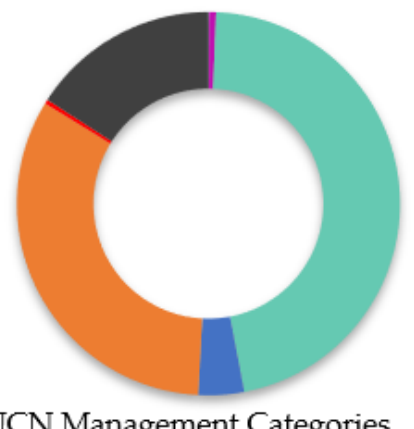

IUCN Management Categories

- Ib 2; $0.06 \%$

- II $18 ; 0.58 \%$

IV $1433 ; 46.36 \%$

- V 119; $3.85 \%$

Not Reported 1017; 32.9\%

not Applicable 11; $0.36 \%$

- Not Assigned 491; $15.88 \%$

(a)

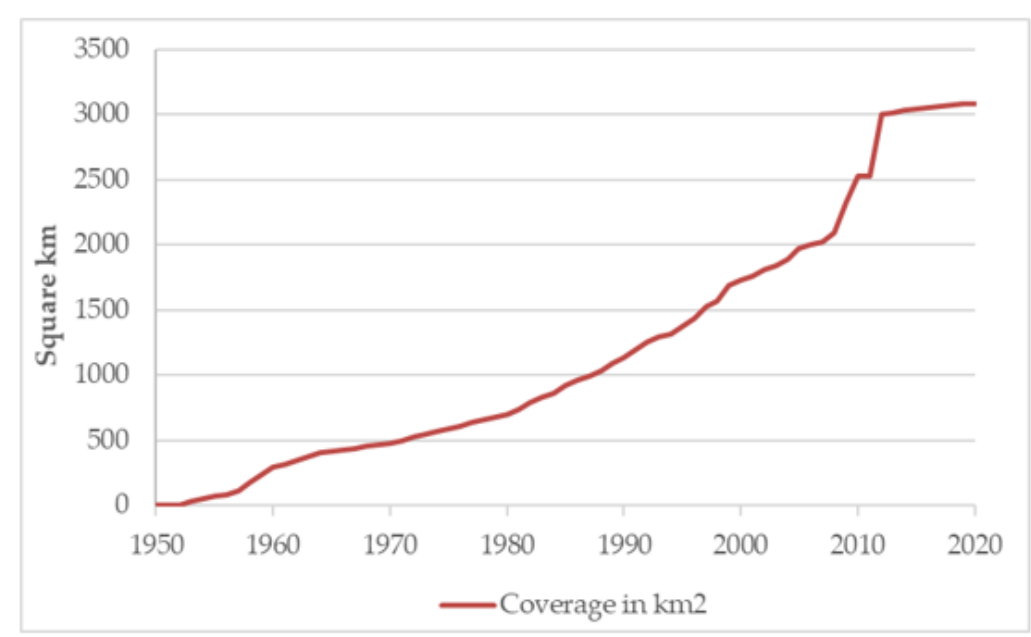

(b)

Figure 3. Protected areas in Poland according to the International Union for Conservation of Nature (IUCN). (a) Management Categories; (b) growth in protected area coverage in Poland (status years 1950 = 0) (source: https: / / www.protectedplanet.net/country/POL, accessed on 7 May 2021) UNEPWCMC, May 2021). 
National parks and reserves are the most important forms of protected areas. Nature Reserves cover the areas preserved in their natural or slightly changed state, ecosystems, refuges and natural habitats, plants, animals, and fungi habitats, as well as elements of an inanimate nature having particular environmental, scientific, cultural, and landscape values. These are small areas (1499 sites cover a total of about $0.54 \%$ of the territory of Poland); however, they are subject to the strictest restrictions on human activity. Only some are made available to tourists. Twenty-three Polish national parks represent the most important physico-geographical regions [32,33]. They cover the area of particular environmental, scientific, social, cultural, and educational values with a total surface area of no less than 1000 ha, where all environmental elements and landscape values are under protection. In total, they cover an area of 315,054 ha, which is approx. $1 \%$ of the country's area. Additionally, there is a mandatory buffer zone around the park. Almost $60 \%$ of the area of all national parks was under active protection (this means using, if necessary, protective measures to reconstruct distorted natural habitats, plants, animals, and fungi habitats to restore the natural state of ecosystems and nature components or to preserve natural habitats), where $24 \%$ was under strict protection (this means total and permanent abandonment of direct human interference with the state of ecosystems) and 15\% was under landscape protection (i.e., preservation of the characteristics of a given landscape).

Landscape parks also cover the areas protected on the account of particular environmental, scientific, cultural, and landscape values; however, they do not focus on nature, but their different natures due to natural, ecological, cultural, or landscape values, serving to popularize these values in the conditions of sustainable development [34]. This large-scale form of nature protection belongs to Category $\mathrm{V}$ of the International Union for Nature Conservation-protected landscape [23]. According to the IUCN, areas classified under this category should guarantee a properly balanced coexistence between people and nature. Analogous forms of nature protection exist in most European countries, but they are named differently (local national parks, regional parks, etc.). Outside Europe, they have no unequivocal counterpart.

The largest area of Poland (22\%) is covered by protected landscape areas; however, their boundaries partially overlap with other forms of nature protection. It is a form of nature conservation with a lower rank than national parks, though performing similar tasks $[26,33,35]$. They are frequently created in such a way that they connect to the closely located national parks or landscape parks. That way, additional buffer zones are formed, which may play the role of green corridors.

Landscape nature-protected complexes are small areas created by local governments to protect fragments of natural or cultural landscape to preserve their scenic or aesthetic values. In total, they occupy $0.4 \%$ of the country's area. They may include natural and cultural landscapes. This form of nature conservation is more object-oriented, and covers other sections of river valleys, old river beds, ponds, historic palaces, and mansion parks, as well as locations of old-growth forests, picturesque rocks, post-glacial formations, and dunes [26,33].

The Natura 2000 Network is the youngest form of nature protection, introduced in Poland in 2004 (although preparations for its introduction began at the end of the 1990s) as one of the obligations related to the country's accession to the European Union [36,37]. The European Ecological Network Natura 2000 is an international, world-unique enterprise concerned with the protection of European biodiversity. Natura 2000 is an ecological network composed of sites designated under the Birds Directive (Special Protection Areas, SPAs) and the Habitats Directive (Sites of Community Importance, SCIs, and Special Areas of Conservation, SACs) [38]. These sites are created independently and they intersect and partially overlap with each other, as well as coincide with other forms of national protection, which must be taken into account during spatial analyses. Despite great difficulties and resistance from the authorities at the beginning of the implementation of the Directives in Poland [36,39], the Natura 2000 network currently covers almost 20\% of Poland's land area. It includes 850 habitat sites and 145 bird sites, and in 2021, even the number of SCI areas 
was increased to 864 . Environmental monitoring and appropriate conservation activities formalized at the EU level were conducted for all areas.

Other forms of nature protection, such as ecological areas and documentary sites, cover less than $0.5 \%$ of national forms of area-based nature protection [27], and largely overlap with those previously discussed; therefore, they were not taken into account for further analysis. Moreover, they are more object-oriented than area-oriented forms of nature conservation.

\subsection{Data and Research Procedure}

The research procedure consisted of five steps, shown in Figure 4. Data preparation included the analysis of changes in the boundaries and the area of protected areas from 2000 to 2018. The reference data was the vector database of the Central Register of Nature Protection Forms (CRNPF) provided by the General Directorate for Environmental Protection. It contained the boundaries (in the form of polygons) of all forms of nature protection in Poland. Unfortunately, some objects had invalid geometry (such as ring self-intersection, duplicated vertices, repeated point, not closed rings) and required inspection and fixing before performing spatial analyses. Boundaries of nature protection forms created in this way were compared with the boundaries shown on topographic maps on a scale of 1:10,000 from 1995-2003, as well as with descriptive and literature data. Out of eight area-oriented forms of nature conservation in Poland, five main ones were selected for further analyses. The forms covering the largest area of the country were selected, the number of which did not change significantly in the analyzed period (items 1-5 in Table 1). The boundaries of these areas were adopted after the geometric fixes in accordance with the database of the CRNPF. Only the land part of PAs (without sea areas) was taken into account in the study (Figure 5).

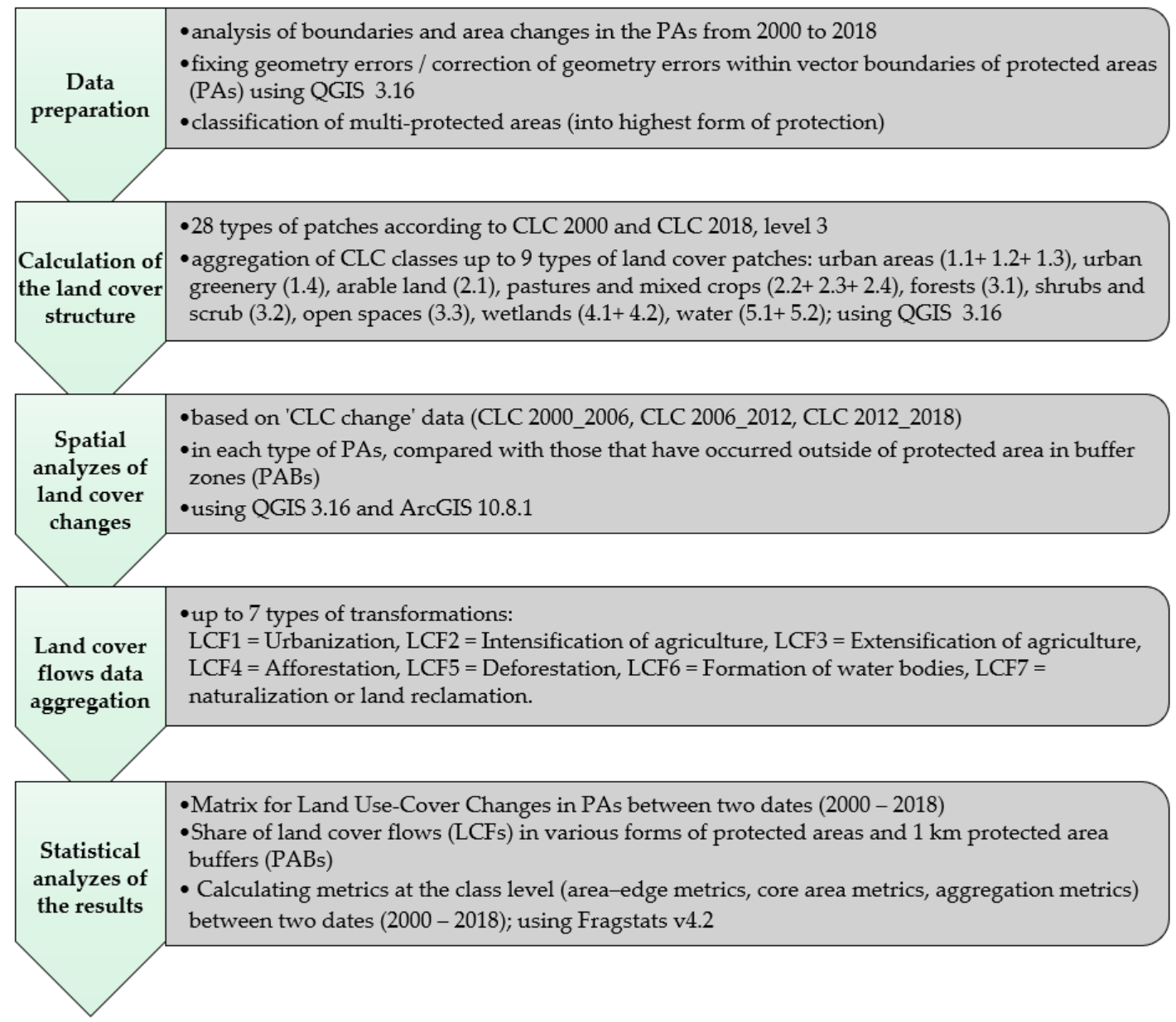

Figure 4. Research procedure. 


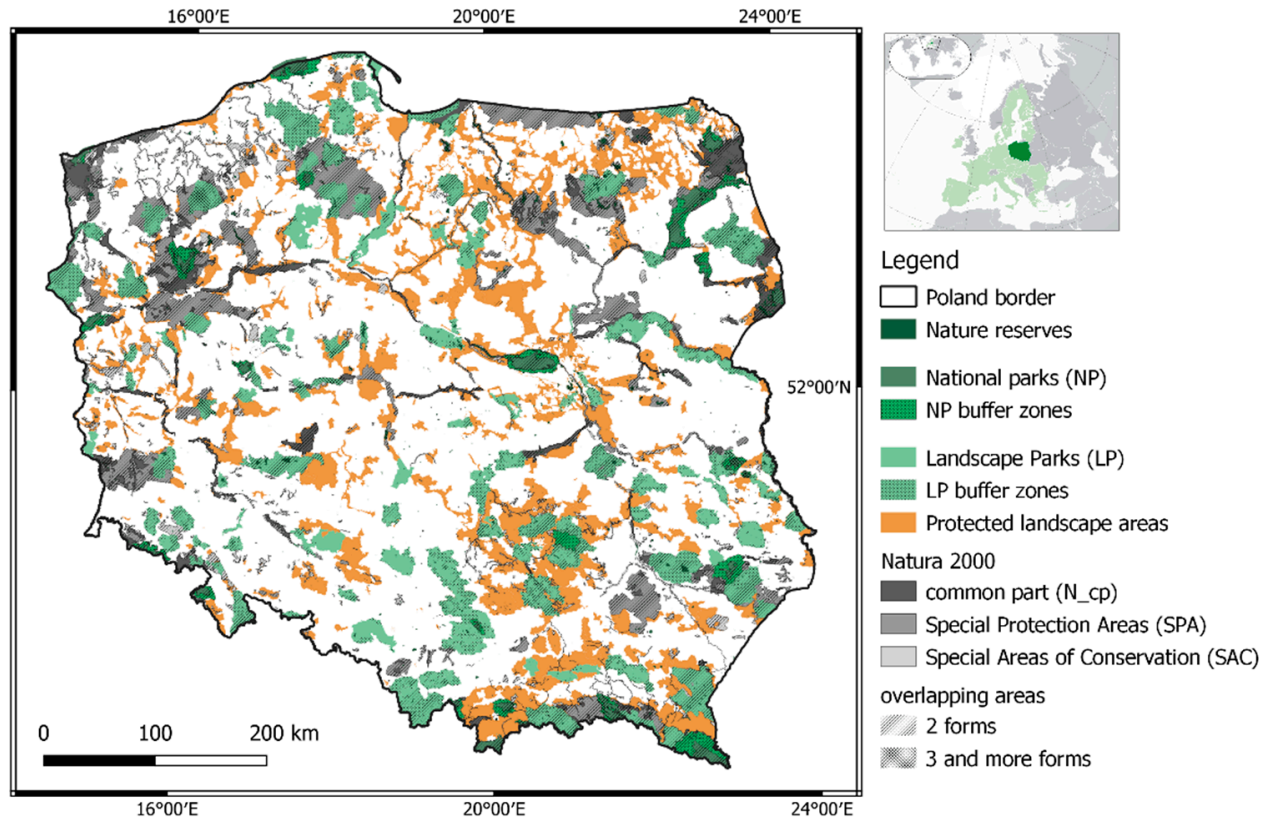

Figure 5. Study area map.

Since the boundaries of the forms of nature protection coincided, classification into one (the highest form of protection) was therefore necessary to avoid counting the same coverage changes multiple times. A given area was always included in the protected landscape areas of highest rank in a given area, following the order shown in Table 1 (nature reserves-the highest rank, protected landscape areas-the lowest rank). Separate polygons have also been designated for a mandatory buffer zone around the national parks (NPz) and landscape parks (LPz). Among Natura 2000 areas (located outside reserves, national parks, or landscape parks), the following polygons were separated: Habitats' Special Areas of Conservation (N_SAC), Birds' Special Protection Areas (N_SPA), as well as a common part of Bird and Habitat Areas (N_cp) (Figure 5).

In the second step, the land cover in the selected PAs and designated $1 \mathrm{~km}$ buffer zones around protected areas (PABs) in 2000 and 2018 were compared. The CORINE land cover (CLC) classes were aggregated up to nine patches: urban areas, urban greenery, arable land, pastures and mixed crops, forests, shrubs and scrub, open spaces with little or no vegetation, wetlands, and water. The CLC data series in a $100 \mathrm{~m}$ grid resolution is a key background reference dataset across Europe. It is widely recognized that the CORINE dataset has some key limitations [40,41]: it has a relatively large minimum mapping unit of 25 hectares, was designed as a pan-European dataset and not as a national data set, and its classification structure and spatial resolution have been designed to fit the wide range of environmental regions of Europe and not any one country. On the other hand, many authors have discussed the quality of CORINE land cover change layers and concluded that the overall thematic accuracy of CORINE land cover change data was found to be high [42-44] and that they are suitable for the calculation of land cover flows [45,46]. Geoprocessing was performed using QGIS 3.16 Conversion from SHP files to integer grid files in the GeoTIFF format, which was done using ArcGIS Desktop 10.8.1 software. The cell size, defining the size of each grid in the GeoTIFF file, was $50 \times 50 \mathrm{~m}$.

In the third step, spatial analyses of land cover changes were conducted. The CORINE Land Cover Change (CLC CHA) data used in the work for the periods 2000-2006, 2006-2012, and 2012-2018 mapped all changes with an area of over 5 ha, and the thematic accuracy was over $85 \%$. Additionally, verification based on high-resolution layers-HRL (Imperviousness, Forest Type, Permanent grassland, Water bodies) and national data-was performed. Supplementary data sources were: orthophotos from aerial photos (2001-2019), topographic databases and topographic maps (1: 10,000), forest maps of the State Forests, data from 
Central Register of Nature Protection Forms, and some statistical data. These additional data sources were mostly used to verify changes in mixed classes that could be considered to be ambiguous and overlap in their description and content (e.g., "241 annual crops associated with permanent crops" or "243 land principally occupied by agriculture with significant areas of natural vegetation", "324 transitional woodland-shrub").

In the fourth step, the recorded land cover changes were classified into seven main types of land cover flows (LC flows) describing major change processes: urbanization (LCF1), intensification of agriculture (LCF2), extensification of agriculture (LCF3), afforestation (LCF4), deforestation (LCF5), formation of water bodies (LCF6), and naturalization or land reclamation (LCF7). The collected materials were subjected to spatial analysis in the QGIS 3.16 and ArcGIS Desktop 10.8.1 software.

In the last step, the results were analyzed in two ways. On the one hand, Land UseCover Changes between two dates (2000-2018) for all forms of nature protection were analyzed together so as to investigate which land use classes in protected areas were the most stable (permanent), and which underwent the most frequent transformations. To quantify spatial patterns and their changes over time, Fragstats 4.2 software was used. The main interest was in quantifying how land cover types and spatial patterns have changed over time in protected areas (PAs) and buffer zones around them (PABs). Therefore, metrics at the class level were calculated. Three types of metrics were calculated, including areaedge metrics, core area metrics, and aggregation metrics (Table 3). The fixed edge depth was set to $100 \mathrm{~m}$ because effects of edges are detected even at this large of a distance from some land cover types (i.e., forest). "Count all as edge" was selected to specify what "edge" was. Parameters for the edge contrast or similarity boxes were not specified.

Table 3. Selected metrics calculated at the class level for nine aggregated land cover patches using FRAGSTATS 4.2.

\begin{tabular}{|c|c|c|}
\hline Metric Groups & Metrics & Description \\
\hline \multirow{4}{*}{ Area-Edge } & CA & $\begin{array}{l}\text { Class area (ha) equals the total area of all grids of a given } \\
\text { class/land cover type }\end{array}$ \\
\hline & PLAND & $\begin{array}{l}\text { Percentage of Landscape, comprised of that land cover } \\
\text { type/class }\end{array}$ \\
\hline & AREA_MN & $\begin{array}{l}\text { Mean patch size (ha) equals the mean size of cell groupings } \\
\text { comprised of the same land cover types. }\end{array}$ \\
\hline & $\mathrm{TE}$ & $\begin{array}{l}\text { Total edge }(\mathrm{m}) \text { equals the total edge length of a particular } \\
\text { land cover type/class }\end{array}$ \\
\hline \multirow{3}{*}{ Core area } & TCA & $\begin{array}{l}\text { Total Core Area (ha) equals the sum of the core areas for all } \\
\text { patches of the corresponding patch type }\end{array}$ \\
\hline & CPLAND & $\begin{array}{l}\text { Core Area Percentage of Landscape equals the percentage of } \\
\text { the total landscape comprised of the core area for a given } \\
\text { land cover type }\end{array}$ \\
\hline & CORE_MN & $\begin{array}{l}\text { Mean Core Area (ha) equals the average size of patches of } \\
\text { core area for a given land cover type }\end{array}$ \\
\hline \multirow{3}{*}{ Aggregation } & NP & $\begin{array}{l}\text { Number of patches equals the number of homogeneous } \\
\text { areas of the same land cover type within the landscape }\end{array}$ \\
\hline & SPLIT & $\begin{array}{l}\text { Splitting Index equals the total area of a landscape squared } \\
\text { divided by the sum of the areas squared for each individual } \\
\text { patch. Larger values communicate that patches are } \\
\text { more fragmented. }\end{array}$ \\
\hline & LSI & $\begin{array}{l}\text { Landscape shape index provides a standardized measure of } \\
\text { total edge or edge density that adjusts for the size of the } \\
\text { landscape. LSI increases without limit as landscape shape } \\
\text { becomes more irregular. }\end{array}$ \\
\hline
\end{tabular}


On the other hand, land cover flows (LCFs) in various forms of protected areas and $1 \mathrm{~km}$ protected area buffers (PABs) were analyzed to answer the following questions:

- How effective individual types of nature protection are;

- Whether the changes in protected areas are smaller than those in the surrounding $1 \mathrm{~km}$ buffer zones; and

- Which of the forms of nature protection are characterized by the greatest durability of land cover, and thus the stability of ecosystems.

Statistical analyses were performed using Microsoft Excel 2019 and Fragstats 4.2 software.

\subsection{Classification of Major Change Processes}

Based on Feranec et al. [45], seven types of change directions were distinguished (Figure 6). However, the flow classification differed slightly from that proposed by Feranec et al. [45]. The difference was mainly in the LCF7 group, which was also taken into account in further analyses, but only reclamation changes and landscape naturalization processes were grouped here. Unclassified changes were greyed out and not assigned to a rare group. All changes to CLC class type 5xx (water) were classified as LCF6-formation of water bodies. The changes from CLC code 211 to 222 or 231 were classified as an extensification of agriculture, not intensification. Similarly, changes in arable land (21x to $32 x$ were considered changes in naturalization because verification on orthophoto maps showed that it was mainly the effect of overgrowing wasteland. The changes into code 331 were not classified, as verification in aerial photos and the field observations showed that these changes are difficult to identify unambiguously. Land cover flows (LCF1-LCF7) were calculated as areas per area type (i.e., four national forms of nature protection, buffer zones around the national parks and landscape parks, three types of Natura 2000 areas, and $1 \mathrm{~km}$ protected area buffers) for the three periods: 2000-2006, 2006-2012 and 2012-2018. Land cover flows were also calculated as a cumulative value for all protected areas in the period 2000-2018.

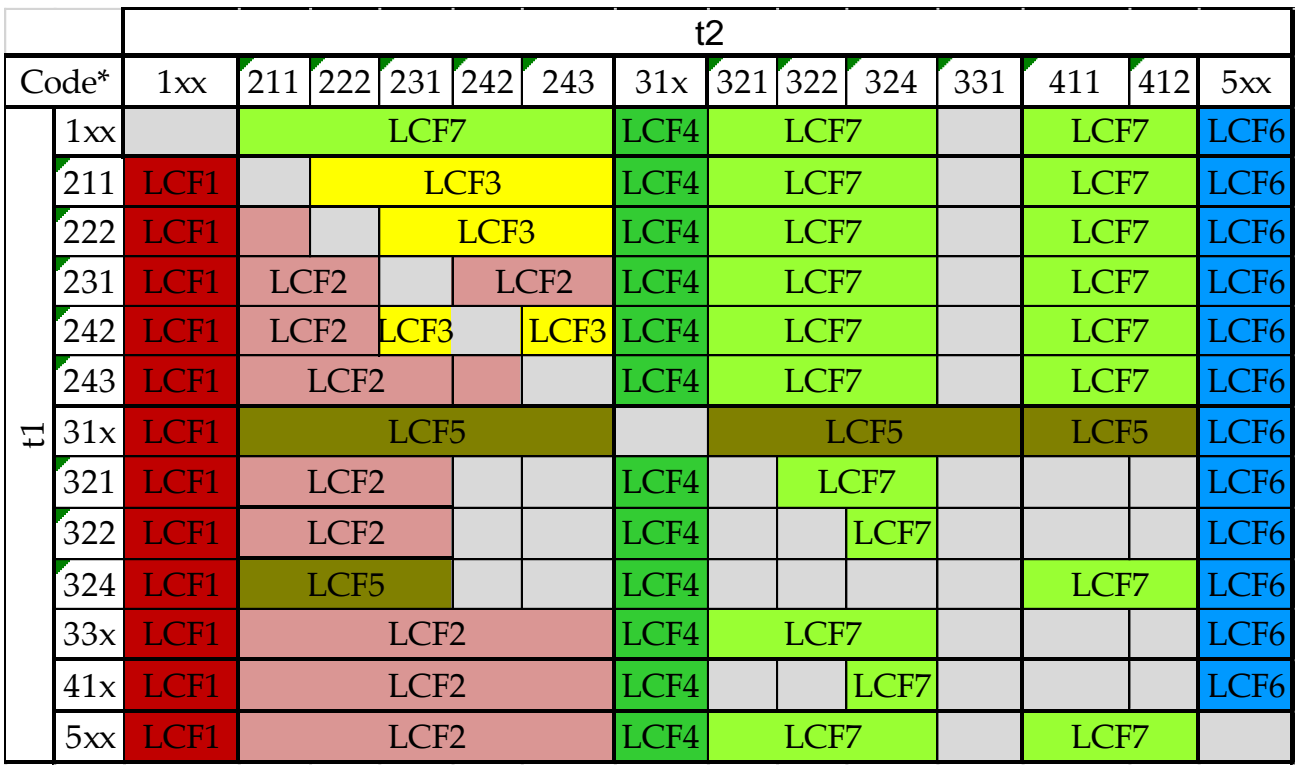

Figure 6. Conversion table-relation between the LC flows and CLC classes. ${ }^{*} 1 \mathrm{xx}, 5 \mathrm{xx}$ - denotes all land cover classes within a given major CLC first-level classification type. 31x, 33x, 41x-means all land cover classes within a given type of land cover from the CLC second level. Classification of major change processes: LCF1-urbanization (red), LCF2 -intensification of agriculture (orange), LCF3-extensification of agriculture (yellow), LCF4-afforestation (green), LCF5—deforestation (brown), LCF6 - formation of water bodies (blue) and LCF7-naturalization or land reclamation (yellow-green), not classified changes (grey). In the rows, the CLC classes for the starting year ( $\mathrm{t} 1$, 2000). In columns, the CLC classes for the final year ( $t 2,2018)$. The meaning of the codes for the CLC classes can be consulted in Jager et al., 2012 [40]. 


\section{Results}

In the analyzed period of 2000-2018, the share of nature conservation areas in the territory of Poland increased from $38 \%$ to almost $44 \%$, mainly due to the implementation of a new form of nature protection (European Ecological Network Natura 2000 sites) and the establishment of a new national park in 2001 (Ujscie Warty). Unfortunately, if we consider only national forms of nature protection, the balance is less optimistic. Although most forms of nature protection increased their area (including an increase in landscape-nature complexes area by over 50\%), the reduction of protected landscape areas by 212,000 hectares resulted in the negative final balance of the national PA forms and amounted to $-56,500$ hectares (a decrease of $0.5 \%$ since 2000 ).

The land cover structure on PAs underwent slight changes. Out of 44 land cover classes identified at level 3 CLC, 32 classes were identified in Poland, including 28 different classes of land cover forms in protected areas. They are dominated by forests (classes 312 and 313) and arable land (class 211), together covering about 92\% of the PAs area in 2000 (Table S1 in Supplementary Materials). The matrix of transformations between land cover classes in PAs is presented in Figure 7. From 2000 to 2018, the most frequently transformed CLC class was 312 (coniferous forest). It was transformed into class 324 (transitional woodland shrubs). Slightly less intense but also quite frequent were transformations in the opposite direction-from class 324 to classes 312 and 313 (mixed forest). However, the area covered by such flows was almost 35\% smaller than that of flows 312-324. Even so, the total forest area increased by $2.43 \%$ between 2000 and 2018 (Table 4 ). Besides artificial surfaces (group 1 in level 1 CLC), water bodies (group 5) were the most stable over time. Small changes were also observed in classes 411 (inland marshes) and 412 (peatbogs). They constituted, respectively, $0.05 \%$ and $0.01 \%$ of all transformations and covered $0.1 \%$ of the areas in class 411 and $0.3 \%$ of areas classified as 412 . As for the transformations towards anthropogenic areas (classes 1xx), they mainly concerned agricultural land, in particular classes 211 (non-irrigated arable land) and 242 (complex cultivation patterns). The area of urbanized areas increased by as much as $85 \%$ and agricultural land decreased by $16 \%$, including the reduction of the area of meadows, pastures, and mixed crops by almost $10 \%$ (Table 4).

The increase in the urbanized areas observed in the protected areas was even greater than in the surrounding buffer zone (Table 4). In contrast to the buffer zone (PABs), in the protected areas (PAs) the average area of urbanized patches (AREA_MN) increased, while the Splitting Index (SPLIT) value decreased, which indicates that these areas are more consolidated. At the same time, the increases in Total Core Area (TCA) and Core Area Percentage of Landscape (CPLAND) shown in Table 5 revealed a $77.4 \%$ increase in urban core areas in PAs and $44.9 \%$ in PABs. In addition, the mean size of urban core areas (CORE_MN) increased by 0.35 ha in PAs and decreased by 4.15 ha in PABs. The rate of increase of urban core areas in PAs and PABs was lower than the rate of increase for the total urban area (Table 4), suggesting that the emergence of isolated urban areas contributes to urban expansion more than the sprawl from existing urban areas. The phenomenon is more intense in the buffer zone. This is also confirmed by the increase in the value of the Landscape Shape Index, which indicates a more irregular shape of built-up areas compared to 2000 . 


\begin{tabular}{|c|c|c|c|c|c|c|c|c|c|c|c|c|c|c|c|c|c|c|c|c|c|c|c|c|c|c|}
\hline & \multicolumn{25}{|c|}{2018} & \multirow[b]{2}{*}{ Total 1} \\
\hline Code & 112 & 121 & 122 & 123 & 124 & 131 & 132 & 133 & 142 & 211 & 222 & 231 & 242 & 243 & 311 & 312 & 313 & 321 & 322 & 324 & 331 & 411 & 412 & 511 & 512 & \\
\hline 112 & & 0 & 14.45 & 0 & 0 & 0 & 0 & 74.53 & 10.72 & 0 & 0 & 0.30 & 0 & 0 & 0 & 0 & 0 & 0 & 0 & 0 & 0 & 0 & 0 & 0 & 0 & 0.04 \\
\hline 121 & 0 & & 18.09 & 0.00 & 0 & 0 & 0 & 81.91 & 0 & 0 & 0 & 0 & 0 & 0 & 0 & 0 & 0 & 0 & 0 & 0 & 0 & 0 & 0 & 0 & 0 & 0.00 \\
\hline 124 & 100 & 0 & 0 & 0 & & 0 & 0 & 0 & 0 & 0 & 0 & 0 & 0 & 0 & 0 & 0 & 0 & 0 & 0 & 0 & 0 & 0 & 0 & 0 & 0 & 0.00 \\
\hline 131 & 0 & 0.96 & 0 & 0 & 0 & & 8.75 & 0 & 0 & 14.60 & 0.00 & 14.85 & 0 & 1.54 & 0 & 0 & 0 & 0 & 0 & 40.87 & 0 & 0 & 0 & 0 & 18.42 & 0.54 \\
\hline 132 & 0 & 0 & 0 & 0 & 0 & 0 & & 0 & 0 & 0 & 0 & 9.78 & 0 & 0 & 0 & 0 & 0 & 0 & 0 & 75.92 & 0 & 0 & 0 & 0 & 14.29 & 0.02 \\
\hline 133 & 13.08 & \begin{tabular}{|l|}
3.92 \\
\end{tabular} & 70.04 & 0.26 & \begin{tabular}{|l|}
0.32 \\
\end{tabular} & 0 & 0 & & 0.18 & 3.32 & 0 & 0.37 & 1.38 & 0 & 0 & 0 & 0 & 0 & 0 & 0.88 & 0 & 0 & 0 & 0 & 4.25 & 1.10 \\
\hline 141 & 0 & 0 & 31.40 & 0 & 0 & 0 & 0 & 68.60 & 0 & 0 & 0 & 0 & 0 & 0 & 0 & 0 & 0 & 0 & 0 & 0 & 0 & 0 & 0 & 0 & 0 & 0.00 \\
\hline 142 & 4.63 & 0.94 & 1.59 & 0 & 0.19 & 7.34 & 0.30 & 2.31 & & 0 & 9.89 & 7.29 & 1.19 & 12.84 & 0 & 0 & 0 & 0 & 0 & 49.90 & 0 & 0 & 0 & 0 & 1.57 & 2.62 \\
\hline 211 & 4.29 & 2.56 & 3.69 & 0 & 0.04 & 10.20 & 0.05 & 12.40 & 0.14 & & 2.38 & 2.01 & 3.52 & 11.94 & 0.36 & 0.11 & 0.06 & 0 & 0 & 44.21 & 0 & 0 & 0 & 0.04 & 2.00 & 5.84 \\
\hline 222 & .16 & 1.71 & 2.10 & 0 & 0 & 2.96 & 0 & 1.82 & 2.89 & 16.42 & & 1.29 & 0 & 5.49 & 0 & 0.27 & 0 & 0 & 0 & \begin{tabular}{|l|}
47.38 \\
\end{tabular} & 0 & 0 & 0 & 0 & 16.49 & 0.68 \\
\hline 231 & .29 & 1.52 & 0.92 & 0.04 & 0.23 & 4.81 & 0.22 & 5.91 & 0.26 & 17.55 & \begin{tabular}{|l|}
0.14 \\
\end{tabular} & & 0.87 & \begin{tabular}{|l|}
0.09 \\
\end{tabular} & 0.06 & 0.31 & 0.40 & 0 & 0 & 62.76 & 0 & 0 & 0 & 0 & 2.57 & 3.84 \\
\hline 242 & 1.59 & 1.95 & 6.48 & 0 & 0.07 & 5.84 & 0 & 16.63 & 1.05 & 4.54 & 0 & 0 & & 0 & 0 & 0.56 & 0 & 0 & 0 & 8.32 & 0 & 0 & 0 & 0 & 2.97 & 0.22 \\
\hline 243 & .19 & 0.51 & 1.50 & 0 & 0 & 4.19 & 0.15 & 1.85 & 0.17 & 3.94 & -0 & 0.28 & 0.31 & & 1.11 & 0.77 & 1.19 & 0 & 0 & 78.93 & 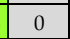 & 0 & 0 & 0 & 3.92 & 2.34 \\
\hline 8311 & 0.06 & 0.02 & 1.10 & 0 & 0.01 & 1.33 & 0 & 1.36 & 0.27 & 0.54 & 0 & 0.77 & 0 & 0 & & 0 & 0.07 & 0.09 & 0 & 93.40 & 0 & 0 & 0.34 & 0 & 0.64 & 2.58 \\
\hline$\checkmark 312$ & 0 & 0.04 & 0.24 & 0 & 0.08 & 0.24 & 0 & 0.93 & \begin{tabular}{|l|}
0.06 \\
\end{tabular} & 0.11 & 0 & 0.09 & 0.01 & 0 & 0 & & 0.01 & 0.02 & 0.01 & 98.05 & 0.08 & 0.01 & 0 & 0 & 0.02 & 42.21 \\
\hline 313 & 0.18 & 0.04 & 0.96 & 0 & 0.05 & 0.41 & 0 & 1.46 & 0.13 & 0.32 & 0 & 0.30 & 0 & 0 & 0.09 & 0.10 & & 0.27 & 0 & 95.53 & 0 & 0 & 0.02 & 0 & 0.12 & 6.03 \\
\hline 321 & 0 & 0 & 0 & 0 & 0 & 0 & 0 & 0.57 & 0 & 0 & 0 & 0 & 0 & 0 & 0 & 0 & 1.64 & & 0 & 96.19 & 0 & 0 & 0 & 0 & 1.59 & 0.60 \\
\hline 322 & 0 & 0 & 0 & 0 & 0 & 0 & 0 & 0 & 0 & 0 & 0 & 0 & 0 & 0 & 0 & 0 & 0 & 0 & & 100 & 0 & 0 & 0 & 0 & 0 & 0.03 \\
\hline 324 & .12 & 0.01 & 0.15 & 0 & 0.05 & 0.25 & 0 & 0.16 & 0.03 & 1.48 & 0 & 1.40 & 0 & \begin{tabular}{|l|}
0.16 \\
\end{tabular} & 8.21 & 53.74 & 34.04 & 0.05 & 0 & & 0 & 0 & 0 & 0 & 0.07 & 30.93 \\
\hline 331 & 0 & 0 & 0 & 0 & 0 & 0 & 0 & 0 & 0 & 0 & 0 & 0 & 0 & 0 & 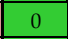 & 0 & 0 & 100 & 0 & 0 & & 0 & 0 & 0 & 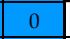 & 0.01 \\
\hline 333 & 0 & 0 & 0 & 0 & 0 & 0 & 0 & 0 & 0 & 0 & 0 & 0 & 0 & 0 & 0 & 0 & 0 & 6.01 & 0.03 & 40.16 & 53.80 & 0 & 0 & 0 & 0 & 0.24 \\
\hline 334 & 0 & 0 & 0 & 0 & 0 & 0 & 0 & 0 & 0 & 0 & - & 0 & 0 & 0 & 0 & 0 & 0 & 0 & 0 & 100 & 0 & 0 & 0 & 0 & 0 & 0.01 \\
\hline 411 & 0 & 0 & 0 & 0 & 0 & 12.39 & 0 & 0 & 0 & 0 & 31.09 & 0 & 0 & 0 & 0 & 0 & 0 & 0 & 0 & 33.49 & 0 & & 0 & 0 & 23.03 & 0.05 \\
\hline 412 & 0 & 0 & 0 & 0 & 0 & 0 & 0 & 0 & 0 & 0 & 0 & 0 & 0 & 0 & 0 & 0 & 0 & 0 & 0 & 0 & 0 & 0 & & 0 & 100 & 0.01 \\
\hline 511 & 0 & 0 & 43.13 & 0 & 0 & 0 & 0 & 17.73 & 0 & 0 & 0 & 0 & 0 & 0 & 0 & 0 & 0 & 0 & 0 & 0 & 0 & 0 & 0 & & 39.14 & 0.00 \\
\hline 512 & 0 & 0 & 0.29 & 0 & 0 & 0 & 0 & 4.96 & 0 & 13.44 & 0 & 29.26 & 0 & 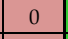 & 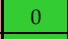 & 0 & 0 & 0 & 0 & 31.81 & 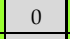 & 20.24 & 0 & 0 & & 0.05 \\
\hline 521 & 0 & 0 & 0 & 0 & 0 & 0 & 0 & 0 & 0 & 0 & 0 & 0 & 0 & 0 & 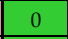 & 0 & 0 & 0 & 0 & 0 & 100 & 0 & 0 & 0 & 0 & 0.01 \\
\hline 523 & 0 & 0 & 0 & 69.1 & 0 & 0 & 0 & 0 & 0 & 0 & 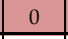 & 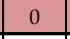 & 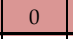 & 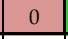 & 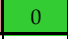 & 0 & 0 & 0 & 0 & 0 & 30.88 & 0 & 0 & 0 & 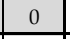 & 0.01 \\
\hline Total 2 & 0.77 & 0.35 & 1.37 & 0.01 & 0.07 & \begin{tabular}{|l|}
1.35 \\
\end{tabular} & 0.07 & 1.71 & 0.10 & 1.54 & 0.42 & 0.93 & 0.30 & 1.14 & 2.59 & 16.67 & 10.59 & 0.07 & 0.01 & 59.03 & 0.19 & 0.01 & 0.01 & 0.00 & 0.70 & 100 \\
\hline
\end{tabular}

Figure 7. Matrix for Land Use-Cover Changes in PAs between two dates (2000-2018), in line with Level 3 of CORINE Land Cover (CLC) with the classification of major change processes: urbanization (red), afforestation (green), deforestation (brown), intensification of agriculture (orange), extensification of agriculture (yellow), formation of water bodies (blue) and naturalization or land reclamation (yellow-green), and non-classified changes (grey). In the rows are the CLC classes for the starting year $(t 1,2000)$. In columns, the CLC classes for the final year $(t 2,2018)$. The meaning of the codes for the CLC classes can be consulted in Jager et al., 2012 [40]. Values in italics mean the percentage share of transformations of individual pairs of classes between 2000 and 2018 (rows sum up to 100). The "Total" value shows the percentage of the area transformed from a given CLC class (Total 1) or into a given CLC class (Total 2) in the total area undergone transformation between 2000 and 2018.

Table 4. Changes in selected area-edge metrics between two dates (2000-2018) calculated at the class level for protected areas (PAs) and $1 \mathrm{~km}$ buffer zones (PABs).

\begin{tabular}{|c|c|c|c|c|c|c|c|c|}
\hline \multirow{2}{*}{$\begin{array}{c}\text { Land Cover } \\
\text { Type }\end{array}$} & \multicolumn{2}{|c|}{ CA [ha] (\%) } & \multicolumn{2}{|c|}{ PLAND [\%] } & \multicolumn{2}{|c|}{ AREA_MN [ha] } & \multicolumn{2}{|c|}{$\mathrm{TE}[\mathrm{m}]$} \\
\hline & PAs & PABs & PAs & PABs & PAs & PABs & PAs & PABs \\
\hline Urban areas & $+188,517$ (85.3) & $+158,290(49.0)$ & 1.41 & 2.98 & 2.3 & -4.83 & $+20,840,050$ & $17,308,300$ \\
\hline Urban greenery & $+8020(61.5)$ & $+4804(25.5)$ & 0.06 & 0.09 & 0.54 & -1.62 & $+691,700$ & $+607,600$ \\
\hline Arable land & $-244,672(-6.5)$ & $-132,426(-5.1)$ & -1.83 & -2.93 & 0.99 & -2.63 & $-12,651,400$ & $-6,680,300$ \\
\hline Pastures ${ }^{1}$ & $-250,453(-9.5)$ & $-127,760(-13.9)$ & -1.87 & -2.58 & -4.14 & -2.01 & $-14,049,450$ & $-13,180,100$ \\
\hline Forests & $+145,255(2.4)$ & $+83,128(7.0)$ & 1.09 & 1.41 & -1.4 & 1.04 & $+6,282,250$ & $+5,323,100$ \\
\hline Shrubs and scrub & $+143,136(66.1)$ & $+50,960(97.2)$ & 1.07 & 0.97 & -8.4 & -0.71 & $+12,803,300$ & $+5,295,800$ \\
\hline Open spaces & $-2529(-18.4)$ & $-895(-22.2)$ & -0.02 & -0.02 & 20.39 & -0.79 & $-228,700$ & $-126,700$ \\
\hline Wetland & $+2680(2.8)$ & $-386(-6.2)$ & 0.02 & -0.01 & -7.13 & -2.73 & $+372,400$ & $-22,800$ \\
\hline Water & $+10,047(2.2)$ & $+5872(7.3)$ & 0.08 & 0.1 & 2.82 & 1.9 & $+529,750$ & $+357,400$ \\
\hline
\end{tabular}

${ }^{1}$ Pastures and mixed crops. 
Table 5. Changes in selected core area and aggregation metrics between two dates (2000-2018) calculated at the class level for protected areas (PAs) and $1 \mathrm{~km}$ buffer zones (PABs).

\begin{tabular}{|c|c|c|c|c|c|c|c|c|c|c|c|c|}
\hline \multirow{2}{*}{$\begin{array}{c}\text { Land Cover } \\
\text { Type }\end{array}$} & \multicolumn{2}{|c|}{ TCA [ha] } & \multicolumn{2}{|c|}{$\begin{array}{c}\text { CPLAND } \\
{[\%]}\end{array}$} & \multicolumn{2}{|c|}{ CORE_MN [ha] } & \multicolumn{2}{|c|}{ NP } & \multicolumn{2}{|c|}{ SPLIT } & \multicolumn{2}{|c|}{ LSI } \\
\hline & PAs & PABs & PAs & PABs & PAs & PABs & PAs & PABs & PAs & PABs & PAs & PABs \\
\hline Urban areas & $+53,952$ & $+99,985$ & 0.4 & 1.88 & 0.35 & -4.15 & 6078 & 4252 & $-2,786,047$ & $-100,039$ & 54.23 & 38.73 \\
\hline Urban greenery & +3431 & +2846 & 0.03 & 0.05 & 0.17 & -1.35 & 271 & 250 & $-29,208,137$ & $-1,661,509$ & 7.68 & 5.96 \\
\hline Arable land & $-157,168$ & $-110,277$ & -1.18 & -2.43 & 0.68 & -2.29 & -2365 & -644 & 2212 & 2403 & -10.45 & -4.63 \\
\hline Pastures $^{1}$ & $-148,921$ & $-83,988$ & -1.11 & -1.7 & -2.77 & -1.32 & -1428 & -2306 & 10,274 & 43,977 & -12.93 & -17.89 \\
\hline Forests & $+87,605$ & $+64,426$ & 0.66 & 1.09 & -2.77 & 0.81 & 450 & 1312 & 21 & -3085 & 5.54 & 5.54 \\
\hline $\begin{array}{c}\text { Shrubs and } \\
\text { scrub }\end{array}$ & $+58,284$ & $+33,493$ & 0.44 & 0.63 & -7.62 & -0.71 & 2650 & 1858 & 203,713 & $-2,027,190$ & 36.72 & 24.97 \\
\hline Open spaces & -1000 & -537 & -0.01 & -0.01 & 12.41 & -0.45 & -54 & -68 & $2,151,017$ & $-7,603,132$ & -3.13 & -2.59 \\
\hline Wetland & 180 & -274 & 0 & -0.01 & $\begin{array}{l}12.41 \\
-6.15\end{array}$ & -1.77 & 67 & 56 & $\begin{array}{r}2,101,011 \\
-24,042\end{array}$ & $2,601,001$ & 2.21 & 0.04 \\
\hline Water & +4919 & +4557 & 0.04 & 0.08 & 1.41 & 1.47 & -7 & 36 & 486 & -808 & 1.03 & 1.27 \\
\hline
\end{tabular}

${ }^{1}$ Pastures and mixed crops.

The core area and aggregation metrics reveal that although the total forest area increased between 2000 and 2018, the average area of the patches (AREA_MN) and the average area of the core (CORE_MN) decreased in PAs (Table S2 in Supplementary Materials). Furthermore, the number of patches increased by 450 within the PAs and by 1312 in the PABs. In addition, the 20.7 increase in Splitting Index shows that there is now more forest patches as compared to 2000, a sign of fragmentation. In the buffer zone, the mean patch and core size increased. Coupled with the declining Splitting Index, this indicates a lesser fragmentation problem. The Total Core Area value, both in the buffer zone and within the protected areas, increased in the analyzed period by almost $7 \%$ and $2 \%$, respectively.

In contrast to forest areas and urban areas, agricultural areas experience decreases in their core and total area. This is the case both within the protected areas and in the buffer zone. Metrics pertaining to aggregation (Table 5) reveal that arable areas and pastures did not only shrink between 2000 and 2018, but it also became more fragmented. It is true that the number of patches (NP) decreased as a result of a reduction in the total arable land area of $6.5 \%$ (in PAs) and $5.10 \%$ (in PABs), and of pastures, meadows, and mixed crops by $9.5 \%$ and $13.8 \%$. However, the splitting index, which increases with more fragmented patches, rose by more than 2000 for arable land and more than 10,000 for pastures and mixed crops in PAs. In the PABs, the splitting index of pastures and mixed crops increased by over 43,000 from 2000 to 2018. These changes in value suggest an increasing fragmentation of these areas.

The changes in spatial patterns of wetlands in the buffer zones around the protected areas are also disturbing. The reduction of the total area (CA), combined with the reduction of the mean patch size (AREA_MN) and mean core area (CORE_MN), as well as the increase of the splitting index (SPLIT), reveal the threat to the stability of these areas. Moreover, within the boundaries of the protected areas, there is also a decrease in the mean area of patches and cores. The number of patches also increased by $67(9.0 \%)$, and the increase in edge length (TE) is more intense $(6.7 \%)$ than the increase in the total area (CA) $(2.8 \%)$ of these areas.

When we summarize the changes in three periods (Figure 8) it can be seen that although the transformation covers only about 0.6 to $1.7 \%$ of the PAs; however, this share increases over the years, mainly due to a significant increase in the share of the deforestation (LCF5) process in relation to the share of afforestation (LCF4), which in the period 2006-2012 has been almost balanced. The change of this trend in subsequent periods is disturbing, but it was not always the result of human influence on protected areas. Urbanization changes (LCF1) came in fourth after naturalization or land reclamation (LCF7). Overall, land cover changes within protected areas were less frequent than outside (Figure 9), although they still amounted to 143,859 hectares (1.24\% of all national forms of protected areas) from 2012 to 2018. In some parts of Europe, urbanization and intensification of agriculture still accounted for up to $25 \%$ of land cover changes within protected areas [21]. There is no such problem in Poland. Urbanization and intensification of agriculture accounted only for $5.6 \%$, $7.2 \%$, and $5.3 \%$ of land cover changes within protected areas in three analyzed periods. 


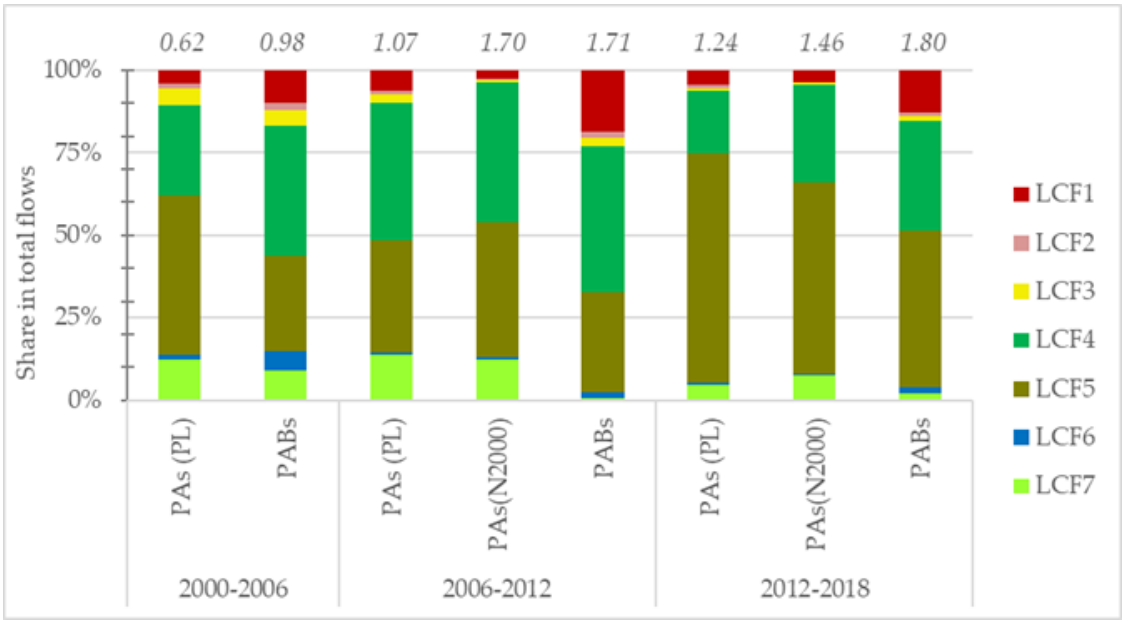

Figure 8. Patterns of land cover flows (LCFs) in protected areas established by Polish law (PAs PL), protected areas under the European Natura 2000 network (PAs N2000), and $1 \mathrm{~km}$ protected area buffers (PABs) as shares of total transformed areas. Values in italics mean the percentage share of the area covered by transformations in the total area of PAs(PL), PAs(N2000), and PABs. LCF1 = Urbanization, LCF2 = Intensification of agriculture, LCF3 = Extensification of agriculture, LCF4 = Afforestation, LCF5 = Deforestation, LCF6 = Formation of water bodies, LCF7 = naturalization or land reclamation.

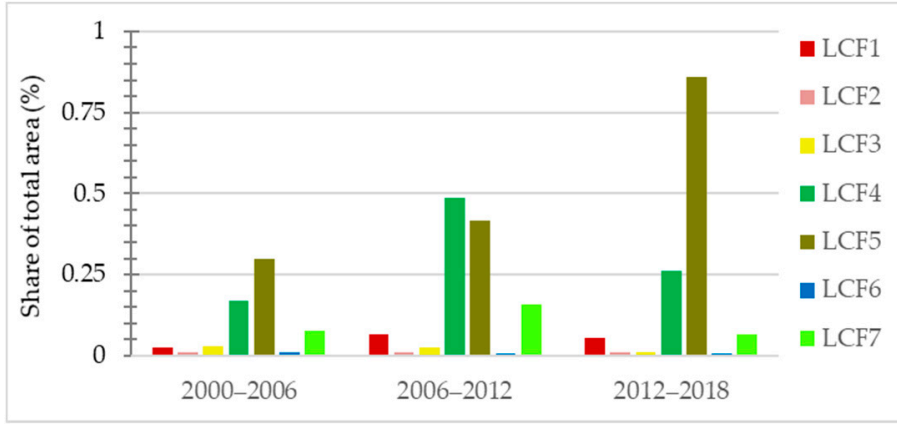

(a)

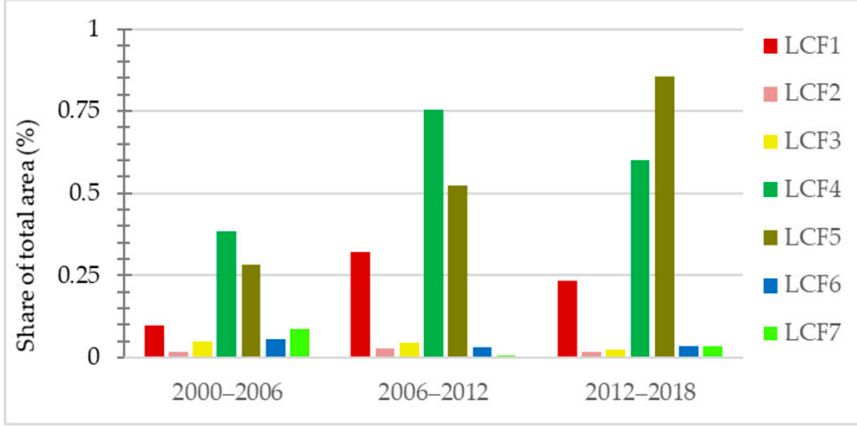

(b)

Figure 9. Land cover flows (LCFs) in protected areas (PAs) (a) and $1 \mathrm{~km}$ protected area buffers (PABs) $(\mathbf{b})$ as shares of total areas. LCF1 = Urbanization, LCF2 = Intensification of agriculture, LCF3 = Extensification of agriculture, LCF4 = Afforestation, LCF5 = Deforestation, LCF6 = Formation of water bodies, LCF7 = naturalization or land reclamation.

The results of land cover flows (LCFs) in various forms of protected areas and $1 \mathrm{~km}$ protected area buffers (PABs) showed that land cover changes were the most frequent in Natura 2000 sites (altogether for bird and habitat sites, it was 3.8\% of the area in the period 2012-2018 and 4.5\% of the area in the period 2006-2012) (Figure 10). This is understandable to some extent, as economic and construction activities are permitted in these areas as long as it does not endanger the habitat or species for which they are established. It is worrying that these changes are greater than in unprotected (buffer) sites. Fortunately, these were only anthropogenic changes to a small extent (they covered only $0.11-0.14 \%$ of the Natura 2000 area). Afforestation and naturalization changes accounted for 38 and 51\% of all transformations. In all the analyzed forms of nature protection, an increase in the share of deforestation processes in relation to afforestation was observed. 


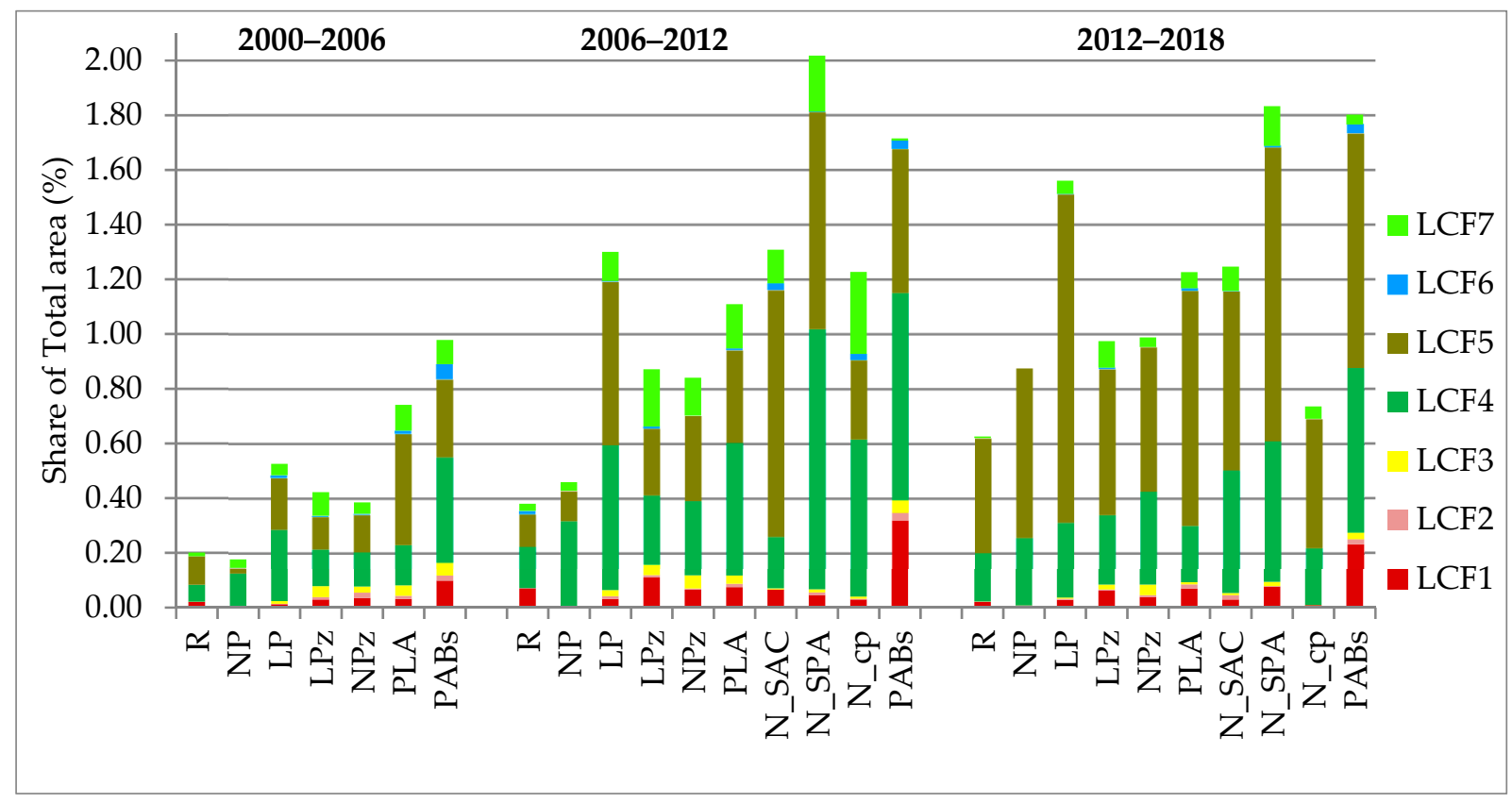

Figure 10. Land cover flows (LCFs) in various forms of protected areas and $1 \mathrm{~km}$ protected area buffers (PABs) as shares of total modeled areas. $\mathrm{R}=$ Nature reserves, $\mathrm{NP}=$ National parks, $\mathrm{LP}=\mathrm{Land}$ scape parks, $\mathrm{LPz} / \mathrm{NPz}=$ parks buffer zones, PLA = Protected landscape areas, N_SAC = Natura 2000 Habitats Special Areas of Conservation, N_SPA = Natura 2000 Birds Special Protection Areas, N_cp = Natura 2000 common part of Bird and Habitat Areas. LCF1 = Urbanization, LCF2 = Intensification of agriculture, LCF3 = Extensification of agriculture, LCF4 = Afforestation, LCF5 = Deforestation, LCF6 $=$ Formation of water bodies, LCF7 = Naturalization/Land reclamation

Nevertheless, the national forms of nature protection adopted in Polish law can be considered effective. National reserves, national parks, and landscapes are subject to slight urbanization changes (LCF 1). The transformations of agricultural and forest areas into anthropogenic areas are the greatest threat and the image of urbanization pressure. In this context, the greatest pressures were recorded in the buffer areas. However, on the other hand, human settlements increased around almost every protected area, potentially increasing human activity along the edges of protected areas and threatening their ecological integrity. Urban expansion around protected areas varied, but overall, their area increased by almost $49 \%$ between 2000 and 2018. In protected areas, this increase was even greater $(85 \%)$, so that the share of urbanized areas in the structure of land use increased by almost $1.5 \%$.

\section{Discussion}

This study concerned three research problems related to land cover changes. First, the land cover flows (LCFs) inside protected areas (PAs) were compared with changes in their immediate surroundings ( $1 \mathrm{~km}$ buffers (PABs) to investigate whether changes in protected areas are smaller than in the surrounding $1 \mathrm{~km}$ buffer zones. The type and spatial patterns of the changes were also important in order to assess the pressure that may be exerted by newly emerging urban areas in the vicinity of national parks or reserves. The pressure on unspoiled areas now has a very specific background. This is because the world's population quadrupled during the 20th century, from 1.5 billion in 1900 to 6.1 billion in 2000 and 7.7 billion in 2020 [47,48]. It is related to an adequate increase in demand for living space and various natural resources necessary for human life and the development of the economy $[29,49,50]$. Even though in Poland, this process was not that intense (population growth from 25 million in 1900 to 38 million in 2000 and is currently at a constant level $[50,51])$, the pressure on natural areas remains strong [52-55]. The research showed that the increase in the area of urbanized areas was over $36 \%$ higher in protected 
areas (PAs) than in $1 \mathrm{~km}$ of protected area buffers (PABs). However, when analyzing urbanization cover flows (LCF1) as shares of total areas, changes in buffer areas were greater than in protected areas in all analyzed periods. In the buffer zone, greater forest total area growth was also observed, with a simultaneous decrease in the area of pastures and mixed crops, as well as open spaces and wetland.

Changes are important not only in the protected areas themselves, but also in their immediate surroundings [56]. The landscape surrounding protected areas influences their ability to maintain ecosystem functions and achieve conservation goals [3,57]. As Jones et al. [58] observed, many of the habitats and resources which influence ecological functioning within National Parks, and protected areas in general, are located outside of their borders in unprotected areas. Hence, land use and land cover changes in surrounding areas may substantially influence the natural resources within parks [3]. As anthropogenic intensification continues, it is important to monitor land-use and land-cover changes not only in protected areas, but also around them [12,19,59].

Lots of conceptual models proposed by researchers $[3,30,59]$ highlight the ecological mechanisms linking protected areas to surrounding lands [8]. It has been recognized that protected areas should be managed in a range larger than their borders to avoid ecological isolation and threat caused by the artificialization of surrounding landscapes $[8,22,60]$. Where formal protection of land is not possible outside the protected area estate, other conservation interventions should be considered (the relevant provisions in spatial development plans are particularly important) $[59,61,62]$. Unfortunately, many local authorities developing Local Spatial Development Plans do not understand that as well as being important for biodiversity in its own right, land outside protected area boundaries can be vital for achieving broader conservation objectives. Without these larger connecting areas of habitat, species can become increasingly isolated within protected areas [8,63-65].

The scale of land cover flows (LCFs) changes within particular forms of protected areas. Therefore, the second research problem of the current study was comparing land cover flows (LCFs) in various forms of protected areas to explore which ones are more effective. The results showed that land cover changes were the most frequent in the Natura 2000 network areas-that is, a form of nature protection having its sources in European law. Unfortunately, it seems that the issue of the international nature of this form of protection, instead of increasing its rank, works in quite the opposite way. This may confirm that the situation described in 2011 by Grodzinska-Jurczak and Cent [36] is still valid-that despite the generally favored attitudes to nature which Polish people generally have, Natura 2000 is perceived as an unnecessary additional conservation tool. Despite numerous promotional activities, both local authorities and communities residing in the Natura areas think that the program is a hindrance, rather than a help in the economic development of municipalities or regions, as was initially supposed. According to Grodzinska-Jurczak and Cent [36], this lack of acceptance results from many factors, mainly social, historic, and economic.

The research revealed that afforestation and naturalization changes had the largest share of all transformations. In all the analyzed forms of nature protection, an increase in the share of deforestation processes in relation to afforestation was observed. The forms with the highest protection rank (such as national parks and reserves) were characterized by the lowest share of the area covered by transformations. This shows the effectiveness of these forms of protection. Additionally, other national forms of nature protection can be considered effective, as changes in these areas are smaller than in the surrounding $1 \mathrm{~km}$ buffer zones, especially when you take into account changes in urbanization or intensification of agriculture. As Symonides [66] emphasized, these systems seem to be an effective tool for the protection of natural resources at the national level. However, one should be aware that the obtained structure of transformations does not apply to all protected areas of a given type equally. The analyses of Krajewski [34] of the intensity of land cover changes in landscape parks in Poland showed that there is a large spatial diversity in this context, depending on the considered period and park location in a given region. In the case of landscape parks, those located in the southern part of Poland are more 
exposed to changes in land cover. It should be noted that in the years 2000-2006 in the case of 25 landscape parks, no changes were observed. In the second period of 2006-2012, no changes were recorded in 18 landscape parks. In the years 2012-2018, in only seven parks, no changes in land cover were identified. Research by Krajewski [34] at selected landscape parks in Lower Silesia (in southwestern Poland) confirmed the thesis of low landscape stability and difficulties in managing this type of protected area, where the interests of various social groups clash with the need for landscape protection $[3,9,10]$.

A similar situation probably also applies to other forms of protection. There are national parks, nature reserves, or protected landscape areas where the landscape has remained unchanged for years, while others are subject to strong transformations. Therefore, to fully answer the question of how effective individual types of nature protection are, it is necessary to supplement the presented research with analyses at the local level. Each object should then be considered individually. As noted by Boitani et al. [67], assessing only land cover changes may be an insufficient method of measuring the effectiveness of the protected area system. Whilst habitat cover is a useful proxy for protected area effectiveness, there is an urgent need for research to assess effectiveness using species data. Basing the evaluation of protected area performance on specific conservation outcomes, as advocated by Boitani et al. [67], it would aid in monitoring an area's practical effectiveness, specifically by tracking certain indicators, such as species richness, phylogenetic distinctiveness, vulnerability, and irreplaceability.

The third research problem was to investigate which land use classes in protected areas are the most stable, and which are under the most frequent transformations. Research has shown that transformation covered only about 0.6 to $1.7 \%$ of the PAs, however, this share increased over the years. A gradual increase in the scale of transformations is noticeable, especially in the years 2012-2018. This confirms the constant trend indicated by other researchers in Europe $[9,19,21,29]$ and other parts of the world (e.g., China) $[2,14,16,20]$. The matrix of transformations between land cover classes in PAs showed that the most frequently transformed CLC class was 312 (coniferous forest). However, these transformations usually took place within the same group of CLC forms (forest and seminatural areas). Besides artificial surfaces, water bodies were the most stable over time. Small changes were also observed in classes 411 (inland marshes) and 412 (peatbogs). Agricultural landscapes are most at risk of loss. The area of meadows, pastures, and mixed crops, as well as arable land not only diminishes over time, but is also under more fragmentation. At a landscape level, several studies have explored the processes and effects of land-use intensification in and around protected areas $[60,68]$. In this context, the scale of landscape transformations in Poland remains at a relatively low level.

The obtained results of patterns of land cover flow (LCFs) in protected areas (PAs) and $1 \mathrm{~km}$ protected area buffers (PABs) are comparable with the results obtained by Hellwig et al. [21], who studied climatic and socioeconomic effects on land cover changes across Europe between 2000 and 2012 depending on the biogeographical region. They also showed more intense changes in the buffer areas than in the protected areas themselves. The structure of flows for protected areas in the first period of 2000-2006 was most similar to the structure for the continental geographic region (the continental), with the share of changes related to agriculture (LCF2 and LCF3) being significantly lower in Poland. The changes observed in the period 2012-2018 were more similar to the system characterizing the Alpine bioregion. As in Helwig's case, also in the analyzed area, afforestation and deforestation (LCF4, LCF5) accounted for the largest part of land cover flows in all area types. The increase in deforestation processes in terms of afforestation observed in Poland was, however, more intense.

Similar results showing the domination of transformations of forest landscapes are presented by Krajewski [34] on the example of landscape parks in Poland. According to his research, in the period 2000-2018, they amounted to $84-90 \%$ of all landscape changes in the areas of landscape parks in Poland. The results of the research covering all national forms of nature protection show that it was $75-88 \%$, and for landscape parks that did not 
coincide with other forms of nature protection, it was 78-90\% of all landscape changes. There is a noticeable increase in the intensification of tree harvesting, which has been taking place in Poland since 2017, not only in the context of the Białowieza Primeval Forest [65] but also in other forest areas, including various protected areas. However, the observed deforestation did not always mean the effect of negative human impact on protected areas. As there are no areas without any human activity in Poland, including no natural primary forests, some changes in the field of deforestation in protected areas could be the result of natural processes, such as forest extinction, as a result of drought or an intermediate stage of restoration forests with a more natural species composition. It is one of the elements of forest management implemented by the Polish State Forests. Natural deforestation caused, inter alia, by strong winds or pests, also has a significant impact. The clear increase in the share of deforestation in all areas (both protected and buffer) is largely the effect of hurricanes that passed through Poland in 2009, 2012, and 2017. As a result of a natural catastrophe in 2017, 79,700 hectares of forests were damaged and practically ceased to exist [69].

The low assessment of Poland in terms of the conservation status of habitats at the EEA Member State level may also result from the inaccurate identification of habitats at the stage of reporting to the Natura 2000 program. Many already protected areas (national and landscape parks) were automatically submitted to the program, based on old results of the nature inventory or assumptions about the habitats present there. The mapping of the location of these areas was carried out based on the existing spatial databases, such as CORINE Biotopes and CORINE Land Cover, the material of protected areas, monitoring of the Birds Refuge, and using topographic maps. There was no possibility of conducting a general inventory of protected habitats and species or detailed field research, and all works were based on published materials, documentation, and the knowledge of naturalists cooperating with the authorities creating the network in Poland [36,37]. Subsequent gradual inventories showed that some habitats were in a different condition than originally assumed. In the following years, several changes were introduced to the Natura 2000 network in Poland, mainly related to the boundaries of individual areas. New areas were also proposed (last update in 2021), and the nature inventory process is still ongoing [70].

\section{Limitations and Further Research Direction}

Remote-sensing is one of the most widely used tools in large-scale analyses of habitat change [40-43], but the resulting data do not always capture fine-scale degradation that does not completely transform the habitat [44-46]. Therefore, the most important limitation of the research was the accuracy of the CORINE Land Cover database (based on the analysis of satellite images for the European area) used in this work. The study showed that the area of changes in PAs during the period 2012-2018 almost tripled in comparison in the period 2000-2006. However, due to the lower accuracy of land cover data for the year 2000 in the CLC database, the actual number and area of the identified changes in the polygons during the period 2000-2006 should be considered uncertain. Hence, additional verification by orthophoto map data and national databases was necessary.

A good summary of the advantages and disadvantages of CLC can be found in Krajewski [34]. The biggest advantage is that the data for the whole of Europe are generally available and collected cyclically every six years. One of the main limitations is a resolution of $100 \times 100 \mathrm{~m}$. Most of the reserves in Poland have an area of less than $1 \mathrm{ha}$, so the changes of $>5$ ha presented in the CLC CHANGE database are too imprecise for detailed analyses in smaller protected areas. That is why further verification of the conclusions made based on more detailed data is planned for the future. It has long been acknowledged that many protected areas may be too small to be viable and that they require careful management to provide conservation benefits in the long term [22]. Indeed, a team by Clark [16] found that it is the smaller protected areas that have proved particularly vulnerable, a result that is also found in other areas around the world [71-73]. "The negative relationship between protected area size and levels of habitat conversion suggests one of two scenarios or a 
combination of both. Firstly, smaller protected areas have, on average, a longer boundary relative to their area, which might increase vulnerability to clearance leaking contagiously across their borders. Additionally, they are often linked to larger-scale ecosystems outside of their boundary and so are heavily influenced by neighboring land cover change. Secondly, larger protected areas tend to be sited in places that are less desirable for anthropogenic use and are less prone to habitat loss" [16]. On the other hand, such smaller forms of nature protection are often easier to go around when designing a new investment, marking the investment route in an alternative site without large financial outlays. For the housing industry, such small green areas, which can then be used by residents for leisure and recreation, are often an additional advantage in increasing the value of the property.

As already mentioned, because the intensiveness and type of transformation are spatially diverse, to assess the effectiveness of each form of nature protection, analyses should be carried out at the local level. The use of the method on a local scale, especially in areas with diverse terrains, should also take changes in topography into account that may result from natural processes or human activity.

In further work, it is worth analyzing whether multi-protection (i.e., covering the same area with several forms of nature protection) has a positive effect on the stability of land cover. The example of Natura 2000 sites where bird and habitat sites overlap shows that these sites undergo less transformation than those covered by only one of these forms of protection.

\section{Conclusions}

The main objective of this research was to identify landscape changes in land use that occurred between 2000 and 2018 in various types of nature protection areas listed in the Polish Central Register of the Forms of Nature Protection and the European Natura 2000 network within the country. This is a novelty in the research carried out so far because usually researchers focused on one form of nature protection, or only on a selected region of the country. In addition, the analysis also covered the buffer zone around protected areas, which is rarely found in works on forms of nature protection in Poland. The deterioration of the habitat conditions in protected areas often results, to a large extent, from external pressure, which is often forgotten.

When we summarized the changes in three analyzed periods, it can be seen that although the transformation covered only about 0.6 to $1.8 \%$ of the PAs, this share increased over the years. Taking into account the most dangerous processes of urbanization (LCF1) and intensification of agriculture (LCF2) for nature, there were more of them in the buffer zone than in protected areas, which may indicate the effectiveness of the protective measures undertaken. The national parks and the nature reserves were characterized by the greatest durability of land cover, and thus the stability of ecosystems. However, urban expansion inside and around protected areas increased as much as over 85 and $48 \%$, potentially increasing human activity along the edges of protected areas and threatening their ecological integrity. Therefore, buffer areas around protected areas should be subject to regular monitoring of land cover changes and control of spatial planning records in these areas. Since, as was shown here, protection is not an automatic consequence of taking legal decisions to protect the area, protected areas should be managed in a range larger than their borders to avoid ecological isolation.

As for the transformations matrix, the research showed that the most stable and permanent land cover classes were water (CLC class 511 and 512) and anthropogenic areas, which was to be expected. However, only a few changes were also noted in class 411 (inland marshes) and 412 (peatbogs). They constituted, respectively, $0.05 \%$ and $0.01 \%$ of all transformations and covered only $0.1 \%-0.3 \%$ of the area of such areas. However, it should be remembered that these are forms of land cover that are difficult to identify from the level of satellite or aerial images, and therefore the data may not be complete. The forests (class 312) were under the most frequent transformations, but its total area increased over time. The largest area was affected by deforestation (both as a result of human activity and natural 
disasters). In 98\%, they were transformed into class 324 (transitional woodland shrubs). Transformations in artificial surfaces accounted for only $1.6 \%$. Afforestation processes were equally intense. In the periods 2000-2006 and 2006-2012, their area was comparable to that of deforestation, and in some forms of nature protection, they even exceeded it. In the period 2012-2018, the deforested area was over three times larger than the afforested area.

The transformations toward anthropogenic land (classes $1 \mathrm{xx}$ ) mainly concerned agricultural land, in particular, classes 211 (non-irrigated arable land) and 242 (complex cultivation patterns). Agricultural landscapes are most at risk of decline and conversion to other land cover forms. The loss of area and fragmentation of meadows, pastures, and other land principally occupied by agriculture with significant areas of natural vegetation are particularly dangerous. This may be one of the main reasons for the poor and bad conservation status of habitats in Poland noted in the EEA reports.

Supplementary Materials: The following supporting information can be downloaded at: https: / / www.mdpi.com/article/10.3390/su14020753/s1, Table S1: Selected area-edge, core area and aggregation metrics between two dates (2000-2018) calculated for protected areas (PAs), Table S2: Selected area-edge, core area and aggregation metrics between two dates (2000-2018) calculated for $1 \mathrm{~km}$ buffer zones (PABs).

Funding: Open access publication was co-financed within the framework of the Polish Ministry of Science and Higher Education's program: "Regional Initiative Excellence" in the years 2019-2022 (No. 005/RID/2018/19)".

Institutional Review Board Statement: Not applicable.

Informed Consent Statement: Not applicable.

Data Availability Statement: The data are available in a publicly accessible repository.

Conflicts of Interest: The author declares no conflict of interest.

\section{References}

1. Watson, J.E.M.; Dudley, N.; Segan, D.B.; Hockings, M. The performance and potential of protected areas. Nature 2014, 515, 67-73. [CrossRef] [PubMed]

2. Loomis, J.; Echohawk, J. Using GIS to identify under-represented ecosystems in the National Wilderness Preservation System in the USA. Environ. Conserv. 1999, 26, 53-58. [CrossRef]

3. DeFries, R.; Hansen, A.; Turner, B.L.; Reid, R.; Liu, J. Land use change around protected areas: Management to balance human needs and ecological function. Ecol. Appl. 2007, 17, 1031-1038. [CrossRef]

4. Costanza, R.; d'Arge, R.; De Groot, R.; Farber, S.; Grasso, M.; Hannon, B.; Van Den Belt, M.; Paruelo, J.; Raskin, R.G.; Sutton, P.; et al. The value of the world's ecosystem services and natural capital. Nature 1997, 387, 253-260. [CrossRef]

5. Gray, C.L.; Hill, S.L.L.; Newbold, T.; Hudson, L.N.; Börger, L.; Contu, S.; Hoskins, A.J.; Ferrier, S.; Purvis, A.; Scharlemann, J.P.W. Local biodiversity is higher inside than outside terrestrial protected areas worldwide. Nat. Commun. 2016, 7, 12306. [CrossRef] [PubMed]

6. Stolton, S.; Dudley, N.; Belokurov, A.; Deguignet, M.; Burgess, N.D.; Hockings, M.; Leverington, F.; MacKinnon, K.; Young, L. Lessons learned from 18 years of implementing the management effectiveness tracking tool (Mett): A perspective from the mett developers and implementers. Parks 2019, 25, 79-92. [CrossRef]

7. Eken, G.; Bennun, L.; Brooks, T.; Darwall, W.R.T.; Fishpool, L.D.C.; Foster, M.; Knox, D.; Langhammer, P.; Matiku, P.; Radford, E.; et al. Key Biodiversity Areas as Site Conservation Targets. BioScience 2004, 54, 1110-1118. [CrossRef]

8. Hansen, A.J.; DeFries, R. Land Use Change around Nature Reserves: Implications for Sustaining Biodiversity. Ecol. Appl. 2007, 17, 972-973. [CrossRef]

9. Le Saout, S.; Hoffmann, M.; Shi, Y.; Hughes, A.; Bernard, C.; Brooks, T.M.; Bertzky, B.; Butchart, S.H.M.; Stuart, S.N.; Badman, T.; et al. Protected Areas and Effective Biodiversity Conservation. Science 2013, 342, 803-805. [CrossRef]

10. Barnes, M.D.; Craigie, I.D.; Harrison, L.B.; Geldmann, J.; Collen, B.; Whitmee, S.; Balmford, A.; Burgess, N.D.; Brooks, T.; Hockings, M.; et al. Wildlife population trends in protected areas predicted by national socio-economic metrics and body size. Nat. Commun. 2016, 7, 12747. [CrossRef]

11. Geldmann, J.; Coad, L.; Barnes, M.D.; Craigie, I.D.; Woodley, S.; Balmford, A.; Burgess, N.D.; Knights, K.; Masica, M.; McRae, L.; et al. A global analysis of management capacity and ecological outcomes in terrestrial protected areas. Conserv. Lett. 2018, 11, e12434. [CrossRef]

12. Kearney, S.; Adams, V.; Fuller, R.; Possingham, H.; Watson, J. Estimating the benefit of well-managed protected areas for threatened species conservation. Oryx 2020, 54, 276-284. [CrossRef] 
13. Craigie, I.D.; Baillie, J.E.M.; Balmford, A.; Carbone, C.; Collen, B.; Green, R.E.; Hutton, J.M. Large mammal population declines in Africa's protected areas. Biol. Conserv. 2010, 143, 2221-2228. [CrossRef]

14. Figueroa, F.; Sánchez-Cordero, V. Effectiveness of natural protected areas to prevent land use and land cover change in Mexico. Biodivers. Conserv. 2008, 17, 3223. [CrossRef]

15. Liu, J.; Linderman, M.; Ouyang, Z.; An, L.; Yang, J.; Zhang, H. Ecological Degradation in Protected Areas: The Case of Wolong Nature Reserve for Giant Pandas. Science 2011, 292, 5514. [CrossRef] [PubMed]

16. Clark, N.E.; Boakes, E.H.; McGowan, P.J.K.; Mace, G.M.; Fuller, R.A. Protected Areas in South Asia Have Not Prevented Habitat Loss: A Study Using Historical Models of Land-Use Change. PLoS ONE 2013, 8, e65298. [CrossRef]

17. Reisig, D.; Mullan, K.; Hansen, A.; Powell, S.; Theobald, D.; Ulrich, R. Natural amenities and low-density residential development: Magnitude and spatial scale of influences. Land Use Policy 2021, 102, 105285. [CrossRef]

18. Zydron, A.; Antkowiak, M.; Lisiak, M.; Szczepański, P. The analysis of urban pressure on protected areas on the example of Puszczykowo commune. Studia I Pr. WNEIZ US 2016, 46, 409-422. [CrossRef]

19. Karen, B.M.; McCleery, R.A.; Binford, M.W.; Zweig, C. Land-cover change within and around protected areas in a biodiversity hotspot. J. Land Use Sci. 2015, 11, 154-176. [CrossRef]

20. Adhikari, A.; Hansen, A.J. Land use change and habitat fragmentation of wildland ecosystems of the North Central United States. Landsc. Urban Plan. 2018, 177, 196-216. [CrossRef]

21. Hellwig, N.; Walz, A.; Markovic, D. Climatic and socioeconomic effects on land cover changes across Europe: Does protected area designation matter? PLOS ONE 2019, 14, e0219374. [CrossRef]

22. Fan, X.; Jiaa, Z.; Daib, X.; Sun, N.; Han, F.; Lu, J. Ecological quality dynamics around marine reserves in the Bohai Sea coastal zone and their relationship with landscape artificialization. Glob. Ecol. Conserv. 2019, 20, e00778. [CrossRef]

23. UNEP-WCMC; IUCN. Protected Planet: The World Database on Protected Areas (WDPA). Protected Area Profile for Poland. May 2021. Available online: www.protectedplanet.net (accessed on 5 May 2021).

24. Nationally designated areas (CDDA) Reported 2020 provided by European Environment Agency (EEA). Available online: https://www.eea.europa.eu/data-and-maps/data/nationally-designated-areas-national-cdda-15 (accessed on 7 May 2021).

25. Jongman, R.H.G. Nature conservation planning in Europe: Developing ecological networks. Landsc. Urban Plan. 1995, 32, 169-183. [CrossRef]

26. Formy Ochrony Przyrody (EN: Forms of Nature Protection). General Directorate for Environmental Protection. Available online: https://www.gov.pl/web/gdos/formy-ochrony-przyrody (accessed on 10 May 2021).

27. Central Register of the Forms of Nature Protection. Available online: crfop.gdos.gov.pl (accessed on 29 March 2021).

28. Conservation Status of Habitat Types Datasets from Article 17, Habitats Directive 92/43/EEC Reporting Provided by EEA. Available online: https: / www.eea.europa.eu/data-and-maps/data/article-17-database-habitats-directive-92-43-eec-2 (accessed on 10 May 2021).

29. Luque, Z.S.; Kostecka, J. Biodiversity loss, the causes, the state and basic form of nature protection in Spain and Poland. Pol. J. Sustain. Dev. 2018, 22, 75-84. [CrossRef]

30. Hansen, A.J.; Piekielek, N.; Davis, C.; Haas, J.; Theobald, D.M.; Gross, J.E.; Monahan, W.B.; Olliff, T.; Running, S.W. Exposure of U.S. National Parks to land use and climate change 1900-2100. Ecol. Appl. 2014, 24, 484-502. [CrossRef]

31. The Nature Conservation Act of 16 April 2004. Journal of Laws No. 151, Item 1220, as Amended. Available online: https: / / isap.sejm.gov.pl/isap.nsf/download.xsp/WDU20040920880/U/D20040880Lj.pdf (accessed on 10 May 2021).

32. Daniszewski, P. Forms of nature protection in Poland. World Sci. News 2013, 1, 9-13.

33. Walczak, M.; Radziejowski, J.; Smogorzewska, M.; Sienkiewicz, J.; Gacka-Grzesikiewicz, E.; Pisarski, Z. Obszary chronione w Polsce, 3rd ed.; Instytut Ochrony Środowiska: Warszawa, Poland, 2001.

34. Krajewski, P. Monitoring of Landscape Transformations within Landscape Parks in Poland in the 21st Century. Sustainability 2019, 11, 2410. [CrossRef]

35. Badora, K. Spatial system of landscape protection in Poland. Diss. Cult. Landsc. Comm. 2014, 23, 73-88.

36. Grodzinska-Jurczak, M.; Cent, J. Expansion of Nature Conservation Areas: Problems with Natura 2000 Implementation in Poland? Environ. Manag. 2011, 47, 11-27. [CrossRef]

37. Wdrażanie Koncepcji Sieci NATURA 2000 w Polsce w Latach 2001-2003. The 1st Report Commissioned by the Ministry of the Environment; Narodowa Fundacja Ochrony Środowiska and Instytut Ochrony Przyrody PAN, Krakow-Warszawa. 2001. Available online: https://www.wigry.org.pl/natura2000/n2000_raport1.htm (accessed on 20 April 2021).

38. European Commission. Natura 2000. Available online: https://ec.europa.eu/environment/nature/natura2000/index_en.htm (accessed on 11 May 2021).

39. Baranowski, M. Prace nad Siecią Natura 2000 w Polsce. In Ekologiczna Sieć Natura 2000 Problem czy Szansa; IOP PAN: Warszawa, Kraków, 2003; pp. 219-227. Available online: https:/ /rcin.org.pl/dlibra/publication/131623/edition/117784 (accessed on 21 June 2021).

40. Jager, A.L. Preparing CORINE Land cover Data for use. JRS Scientific and Technical Reports; Publications Office of the European Union: Luxembourg, 2012; Available online: https://core.ac.uk/download/pdf/38627375.pdf (accessed on 4 April 2021).

41. Büttner, G. CORINE Land Cover and Land Cover Change Products. In Land Use and Land Cover Mapping in Europe. Remote Sensing and Digital Image Processing; Manakos, I., Braun, M., Eds.; Springer Science and Business Media LLC: Dordrecht, Switzerland, 2014; Volume 18, pp. 55-74. 
42. Härmä, P.; Autio, I.; Teiniranta, R.; Hatunen, S.; Törmä, M.; Kallio, M.; Kaartinen, M. Copernicus Land Monitoring $2014-2020$ in the Framework of Regulation (EU) No 377/2014 of the European Parliament and of the Council of 3 April 2014-Final Report. 2020. Available online: https:/ / www.syke.fi/download/noname/\%7B725215CE-EE17-4B5F-A531-CD525425B28C\%7D/144830 (accessed on 6 April 2021).

43. Keil, M.; Esch, T.; Divanis, A.; Marconcini, M.; Metz, A.; Ottinger, M.; Voinov, S.; Wiesner, M.; Wurm, M.; Zeidler, J. Updating the Land Use and Land Cover Database CLC for the Year 2012_ “Backdating” of DLM-DE of the Reference Year 2009 to the Year 2006. In Final Report at the German Aerospace Center (DLR), German Remote Sensing Data Center (DFD), Oberpfaffenhofen. TEXTE 37/2015. Environmental Research of the Federal Ministry for the Environment, Nature Conservation, Building and Nuclear Safety; Umweltbundesamt: Dessau-Roßlau, Germany, 2015.

44. Petrişor, A.I. Using CORINE data to look at deforestation in Romania: Distribution and possible consequences. Urban. Arhit. Construcţii 2015, 6, 83-90.

45. Feranec, J.; Jaffrain, G.; Soukup, T.; Hazeud, G. Determining Changes and Flows in European Landscapes 1990-2000 Using CORINE Land Cover Data. Appl. Geogr. 2010, 30, 19-35. Available online: https://www.sciencedirect.com/science/article/abs/ pii/S0143622809000472 (accessed on 25 March 2021). [CrossRef]

46. Martínez-Vega, J.; Díaz, A.; Nava, J.M.; Gallardo, M.; Echavarría, P. Assessing Land Use-Cover Changes and Modelling Change Scenarios in Two Mountain Spanish National Parks. Environments 2017, 4, 79. [CrossRef]

47. Population Division. World Population Prospects: The 2019 Revision; UN. United Nations, Department of Economic and Social Affairs. 2021. Available online: www.Worldometers.info (accessed on 9 August 2021).

48. Gaston, K.; Brown, L.R.; Flavin, C.; French, H. State of the World 2000. Environ. Conserv. 2001, 27, 414-422. [CrossRef]

49. Szarek-Łukaszewska, G. Contamination of national parks in Poland-Changes in time. Studia Nat. 2006, 54, 189-199.

50. Statistics Poland (GUS). The World Factbook. Available online: https://www.cia.gov/library/publications/the-world-factbook/ geos/pl.html (accessed on 11 August 2021).

51. Statistics Poland (GUS). Population development and changes in age structure in 1950-2016. Available online: https://stat.gov. $\mathrm{pl} / \mathrm{en}$ (accessed on 11 August 2021).

52. Partyka, J. Ruch turystyczny w polskich parkach narodowych. Folia Tur. 2010, 22, 9-23.

53. Łowicki, D. Land use changes in Poland during transformation: Case study of Wielkopolska region. Landsc. Urban Plan. 2008, 87, 279-288. [CrossRef]

54. Brzeziecki, B.; Bielak, K.; Bolibok, L.; Drozdowski, S.; Zajączkowski, J.; Żybura, H. Structural and compositional dynamics of strictly protected woodland communities with silvicultural implications, using Białowieża Forest as an example. Ann. For. Sci. 2018, 75, 89. [CrossRef]

55. Radziejowski, J. Obszary Chronionej Przyrody. Historia, Stan Obecny, Wyzwania Przyszłości; Wszechnica Polska Szkoła Wyższa TWP: Warszawa, Poland, 2011.

56. Parrish, J.D.; Braun, D.P.; Unnasch, R.S. Are we conserving what we say we are? Measuring ecological integrity within protected areas. Bioscience 2003, 53, 851-860. [CrossRef]

57. Mas, J. Assessing protected area effectiveness using surrounding (buffer) areas environmentally similar to the target area. Env. Monit. Assess. 2005, 105, 69-80. [CrossRef]

58. Jones, D.A.; Hansen, A.J.; Bly, K.; Doherty, K.; Verschuyl, J.P.; Paugh, J.I.; Carle, R.; Story, S.J. Monitoring land use and cover around parks: A conceptual approach. Remote Sens. Environ. 2009, 113, 1346-1356. [CrossRef]

59. Margules, C.R.; Pressey, R.L. Systematic conservation planning. Nature 2000, 405, 243-253. [CrossRef] [PubMed]

60. Gimmi, U.; Schmidt, S.L.; Hawbaker, T.J.; Alcántara, C.; Gafvert, U.; Radeloff, V.C. Increasing development in the surroundings of U.S. National Park Service holdings jeopardizes park effectiveness. J. Environ. Manag. 2011, 92, 229-239. [CrossRef] [PubMed]

61. DeFries, R.; Karanth, K.K.; Pareeth, S. Interactions between protected areas and their surroundings in human-dominated tropical landscapes. Biol. Conserv. 2010, 143, 2870-2880. [CrossRef]

62. Vanclay, J.K. The Effectiveness of Parks. Science 2001, 293, 1007. [CrossRef] [PubMed]

63. Jamrozy, G. The occurence and tendencies for change in the numbers of mammals in Polish national parks. Sylwan 2008, 152, 36-44.

64. Chwistek, K. Changes of the species composition and structure of stands of the Gorce National Park during the period 1992-2007. Ochr. Beskidów Zach. 2010, 3, 79-92.

65. Buczyński, P.; Tończyk, G. The importance of national parks for the protection of dragonflies (Odonata) in Poland. Parki Nar. Rez. Przyr. 2004, 23, 357-380.

66. Symonides, E. Ochrona Przyrody; Wydawnictwa Uniwersytetu Warszawskiego: Warszawa, Poland, 2007.

67. Boitani, L.; Cowling, R.M.; Dublin, H.T.; Mace, G.M.; Parrish, J.; Possingham, H.; Pressey, R.L.; Rondinini, C.; Wilson, K. Change the IUCN Protected Area Categories to Reflect Biodiversity Outcomes. PLoS Biol. 2008, 6, e66. [CrossRef]

68. Davis, C.R.; Hansen, J.A. Trajectories in land use change around U.S. National Parks and challenges and opportunities for management. Wiley Collect. 2016. [CrossRef]

69. Wind damage map-Department of Forest Protection of DGLP. 18 August 2017. Available online: https://www.gdansk.lasy.gov $\mathrm{pl} /$ aktualnosci/-/asset_publisher/1M8a/content/straty-w-lasach-wciaz-rosna (accessed on 20 July 2021).

70. Obszary Natura 2000, General Directorate for Environmental Protection. Available online: https://natura2000.gdos.gov.pl/ natura-2000-w-polsce (accessed on 17 May 2021). 
71. McCleave, J.M. The Regional Integration of Protected Areas: A study of Canada's National Parks. Ph.D. Dissertation, University of Waterloo, Waterloo, ON, USA, 2008; p. 366.

72. Ervin, J.; Mulongoy, K.J.; Lawrence, K.; Game, E.; Sheppard, D.; Bridgewater, P.; Bennett, G.; Gidda, S.B.; Bos, P. Making Protected Areas Relevant: A guide to integrating protected areas into wider landscapes, seascapes and sectoral plans and strategies. $C B D$ Tech. Ser. 2010, 44, 94.

73. Maiorano, L.; Falcucci, A.; Boitani, L. Size-dependent resistance of protected areas to land-use change. Proc. R. Soc. Lond. B. Biol. Sci. 2008, 275, 1297-1304. [CrossRef] [PubMed] 